
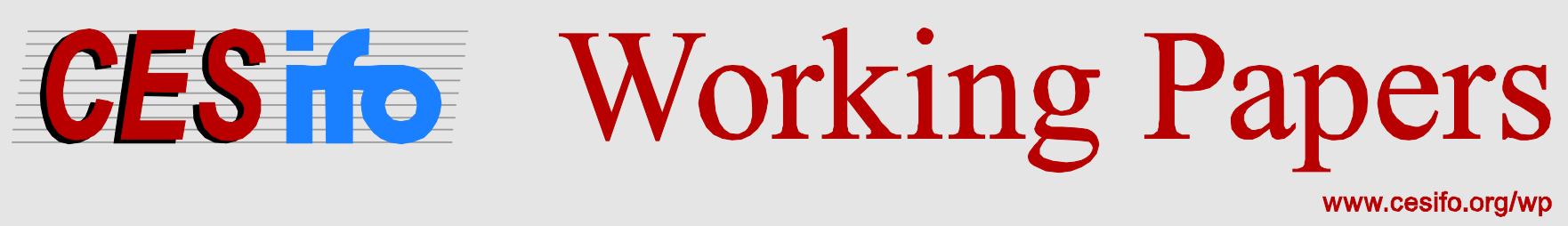

\title{
Unconventional Fiscal Policy, Inflation Expectations, and Consumption Expenditure
}

\author{
Francesco D’Acunto \\ Daniel Hoang \\ Michael Weber
}

\author{
CESIFO WORKING PAPER NO. 5793 \\ CATEgory 6: FisCAL POLICY, MaCroeconomics ANd GROWTH \\ MARCH 2016
}

An electronic version of the paper may be downloaded

- from the SSRN website:

- from the RePEc website:

- from the CESifo website:

WWW.SSRN.com

Www.RePEc.org

www.CESifo-group.org/wp

ISSN 2364-1428

CESifo 


\title{
Unconventional Fiscal Policy, Inflation Expectations, and Consumption Expenditure
}

\begin{abstract}
Unconventional fiscal policies incentivize households to accelerate consumption by generating future consumer price ination, and offer an alternative to unconventional monetary policy (Correia et al. (2013)). We use a natural experiment to study the causal effect of unconventional fiscal policies on consumption expenditure via the inflation-expectations channel. The German administration unexpectedly announced in November 2005 a three-percentage-point increase in value-added tax (VAT) effective in 2007. This shock increased German households' inflation expectations during 2006, as well as actual inflation in 2007. Matched households in other European countries serve as counterfactuals in a difference-in-differences identification design. German households' willingness to purchase durable goods increased by 34\% after the shock, compared to matched foreign households. Income or wealth effects do not appear to drive these results, and we do not find evidence of intratemporal substitution from non-durable to durable consumption.
\end{abstract}

JEL-Codes: D120, D840, D910, E210, E310, E320, E520, E650.

Keywords: durable consumption, zero lower bound, fiscal and monetary policy, survey data.

Francesco D’Acunto

Haas School of Business

University of California at Berkeley

Berkeley / California / USA

francesco.dacunto@haas.berkeley.edu

\author{
Daniel Hoang \\ Department for Finance and Banking \\ Karlsruhe Institute of Technology \\ Karlsruhe / B-W / Germany \\ daniel.hoang@kit.edu
}

\author{
Michael Weber* \\ Booth School of Business \\ University of Chicago \\ Chicago / IL / USA \\ michael.weber@chicagobooth.edu
}

*corresponding author

This version: February 2016 
Acknowledgements:

This research was conducted with restricted access to Gesellschaft für Konsumforschung (GfK) data. The views expressed here are those of the authors and do not necessarily reflect the views of GfK. We thank the project coordinator at GfK, Rolf Buerkl, for help withthe data and insightful comments. We also thank Rudi Bachmann, David Berger, Carola Binder, Jeff Campbell, Robert Chirinko, John Cochrane, George Constantinides, Giancarlo Corsetti, Yuriy Gorodnichenko, Gary Gorton, Refet Guerkaynak, Anne Hannusch, Jean-Paul L’Huillier, Erik Hurst, Greg Kaplan, Emi Nakamura, Andy Neuhierl, Andreas Neus, Ali Ozdagli, Jonathan Parker, Ĺuboš Pástor, Carolin Pueger, Christian Speck, Amir Sufi, Martin Ruckes, Andrea Tambalotti, Giorgio Topa, Joe Vavra, Johannes Wieland, Mike Woodford, and seminar participants at the AEA 2016, Atlanta Fed, Banque de France, Bank of Italy, UC Berkeley, Bilkent University, Bocconi, Bundesbank, Cambridge, Chicago, the Chicago Junior Macro and Finance Meetings, 2015 CITE, the Cleveland Fed Conference, EEA 2015, EIEF, Federal Reserve Board, 8th joint French Macro Workshop, the 5th meeting of the Macro-Finance Society, 2015 Ifo Conference on Macroeconomics and Survey Data, NBER ME 2015, 2015 RBA Quantitative Macro Workshop, SED 2015, and Yale for valuable comments. Weber gratefully acknowledges financial support from the University of Chicago, the Neubauer Family Foundation, and the Fama-Miller Center. 


\section{Introduction}

Macroeconomists often prefer monetary policy to fiscal policy as a tool to stabilize business cycles. Fiscal policy is typically only effective with a lag, and results in permanent deficits with higher nominal interest rates and distortionary taxes. In addition, a high marginal propensity to save out of temporary tax cuts might result in low fiscal multipliers. ${ }^{1}$

The zero-lower bound on nominal interest rates, however, constrains the effectiveness of monetary policy during liquidity traps. Macroeconomists have recently proposed unconventional fiscal policy measures which increase the incentives to accelerate consumption by changing intertemporal prices. These measures do not rely on income effects, and can stimulate the economy in a budget-neutral way. ${ }^{2}$ Unconventional fiscal policies could offer a revenue-neutral alternative to (unconventional) monetary policy in a world with large government budget deficits and inflated central bank balance sheets. ${ }^{3}$

Feldstein (2002) introduces the notion of "unconventional" fiscal policy during liquidity traps. He proposes a series of pre-announced increases in the value-added tax (VAT) to generate consumer price inflation, and hence increase private spending via intertemporal substitution. ${ }^{4}$ Hall (2011) reiterates these ideas, and Correia, Farhi, Nicolini, and Teles (2013) formalize them. They show unconventional fiscal policies, including higher future consumption taxes, can completely offset the zero-lower-bound constraint on nominal interest rates by generating consumer price inflation without distorting production decisions.

This paper documents a positive, causal effect of an unconventional fiscal policy measure on households' willingness to purchase durable goods through an inflationexpectations channel. We exploit an unexpected announcement of a future increase in VAT in Germany passed to comply with European Union Law. In November 2005, the newly formed German administration unexpectedly announced a three-percentage-point increase in the VAT, effective in January 2007. The administration legislated the VAT

\footnotetext{
${ }^{1}$ Researchers debate the size of fiscal multipliers, with recent estimates based on exogenous government spending finding estimates below 1 (see Ramey (2011b) and Barro and Redlick (2011)). Ramey (2011a) and Ramey (2015) provide an excellent overview of the literature.

${ }^{2}$ A literature studying unconventional monetary policy measures, such as forward guidance, has also evolved, as we discuss below.

${ }^{3}$ Caballero, Farhi, and Gourinchas (2015) develop a model in which liquidity traps spread around the world, and secular stagnation can be the new norm for global macroeconomic conditions.

${ }^{4}$ Feldstein (2002): "This [VAT] tax-induced inflation would give households an incentive to spend sooner rather than waiting until prices are substantially higher."
} 
increase to consolidate the federal budget and avoid a formal infringement procedure and fines for the breach of the Maastricht Treaty. The Treaty mandates that EU member countries run yearly budget deficits below $3 \%$ of GDP. The VAT increase was unrelated to prospective economic conditions in Germany, and it qualifies as an exogenous tax change due to inherited fiscal deficits in the taxonomy of Romer and Romer (2010). In section V, we argue in more detail why this shock was unrelated to future economic conditions, and was exogenous to German households' expectations regarding current and future income.

The European Central Bank (ECB) is responsible for the monetary policy and price stability of all countries in the Euro Area, including Germany. The ECB explicitly excluded an increase in nominal interest rates to counteract the announcement of a higher VAT in Germany, because they believed the increase in consumer price inflation would be temporary and limited to Germany.

Our empirical design uses matched households in EU countries not exposed to the VAT shock as a control group for German households, in a difference-in-differences identification strategy. The VAT shock increased German households' inflation expectations in 2006, and actual inflation increased in 2007. The shock did not affect inflation expectations of households in other European countries. We find a large and significant treatment effect of the pre-announced VAT increase on German households' willingness to purchase durable goods.

We implement our empirical strategy using micro data from the market research firm GfK. GfK surveys a representative set of 2,000 German households on a monthly basis to measure expectations about business-cycle conditions on behalf of the European Commission. We first analyze the cross-sectional association between households' inflation expectations and their willingness to purchase durable goods across European countries. This exercise aims to verify that European households change their consumption decisions as they change their inflation expectations, which is a necessary condition for the VAT shock to affect consumption through the inflation-expectations channel. ${ }^{5}$

Based on a sample from January 2000 through December 2013, Figure 1 shows a positive correlation between German households' inflation expectations and their willingness to purchase. The figure plots the average monthly willingness across surveyed households to purchase durable goods, against the share of households that expect

\footnotetext{
${ }^{5}$ The literature is inconclusive regarding the sign of the empirical association between inflation expectations and consumption choices, as we discuss below.
} 
inflation to increase in the following 12 months. The solid line is the slope of a regression of the average willingness to purchase durable goods on our measure of inflation expectations. ${ }^{6}$ A positive correlation of 0.59 is present between inflation expectations and the readiness to spend on durable goods. This positive correlation is statistically different from zero throughout the sample period, and its size is larger after the announcement and before the effectiveness of the VAT increase (blue points).

Figure 1: Readiness to spend on durables and inflation expectations

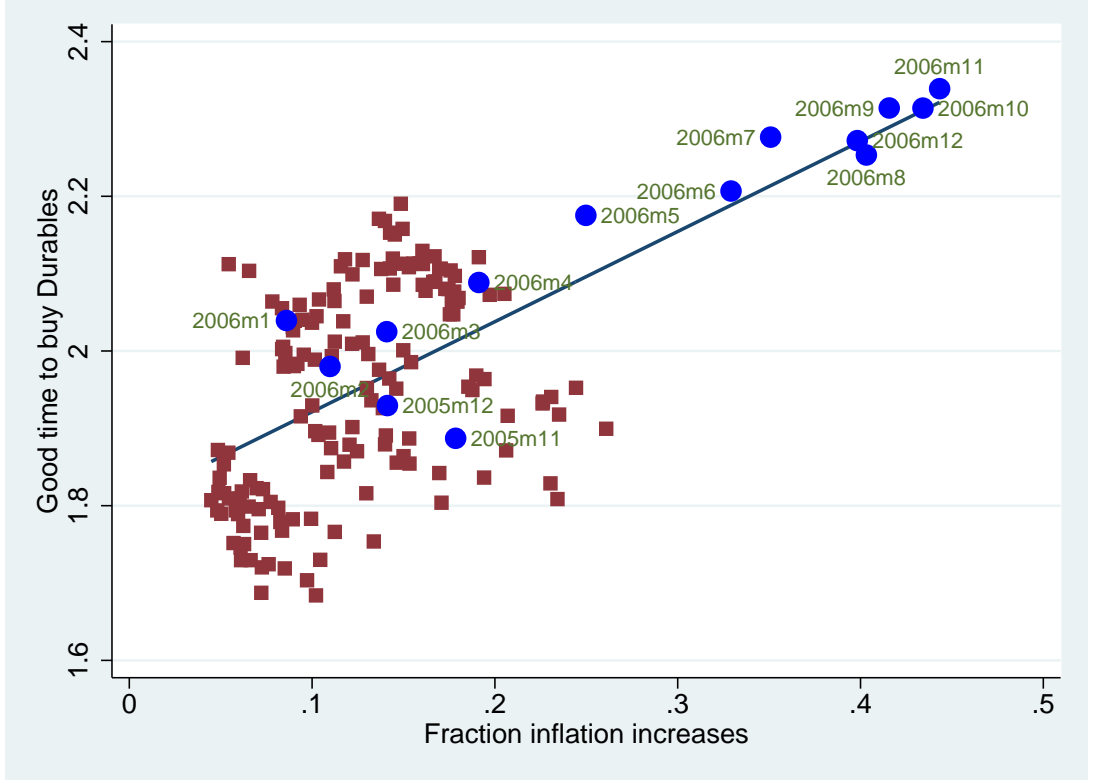

This figure plots the average monthly readiness to purchase durables on the y-axis against the average monthly inflation expectation. We use the confidential micro data underlying the GfK Consumer Climate MAXX survey to construct these variables. GfK asks a representative sample of 2,000 households whether is a good time to purchase durables given the current economic conditions. Higher values correspond to better times. GfK also asks how consumer prices will evolve in the next 12 months compared to the previous 12 months. We create a dummy variable that equals 1 when a household expects inflation to increase. The sample period is January 2000 to December 2013.

In our baseline analysis, we estimate a set of multinomial logit regressions of a categorical variable that describes the willingness of households to purchase durable goods on their inflation expectations. ${ }^{7}$ Households that expect higher inflation are on average $8 \%$ more likely to report it is a good time to buy durable goods, compared to households that expect constant or decreasing inflation. This positive association holds when we

\footnotetext{
${ }^{6}$ We describe the data and the construction of our variables in detail in section II.

${ }^{7}$ All our results are similar if we interpret the answer choices as an ordered set and use an ordered probit model or ordinary least squares to estimate the marginal effect. See Table A.1 in the online appendix.
} 
control for observed household-level heterogeneity with a rich set of demographic variables, and households' expectations regarding other dimensions such as personal income or unemployment. Households expecting higher inflation are also less likely to save, which suggests overall consumption increases with higher inflation expectations. The average marginal effect of inflation expectations varies substantially across demographics. The association is higher for household heads with a college degree, for high-income households, and for non-retired households.

Then, we document the announcement of the VAT increase in November 2005 led to an increase in inflation expectations of Germans in 2006. Realized inflation increased in 2007 after the actual increase in VAT. Within the EU, this pattern was unique to Germany. ${ }^{8}$

The VAT shock alone does not allow us to construct a causal test for the effect of unconventional fiscal policy on consumption expenditure through changes in inflation expectations, because all German households were exposed to the same shock. For identification, we miss a counterfactual: a group of households not affected by the shock, to proxy for the behavior of German households absent the shock. We obtained access to confidential micro data from the same EU business-cycle survey for three additional countries: France, Sweden, and the UK. We first verify households in these countries are also more willing to purchase durable goods when they expect higher inflation consistent with the behavior of German households.

Our identification strategy is based on a difference-in-differences design: we compare German households' willingness to purchase durables with the willingness of households in other European countries, before and after the VAT shock. We match German households with foreign households that are observationally equivalent, because our baseline analysis shows substantial heterogeneity in the marginal effect of inflation expectations on consumption behavior across demographics. Consistent with a causal effect of unconventional fiscal policy on households' purchasing attitudes, we find a large treatment effect of the VAT shock on durable expenditure via increased inflation expectations of German households.

In a neoclassical model, changes in VAT might affect households' decisions to purchase durable goods through income or wealth effects rather than inflation expectations. We

\footnotetext{
${ }^{8}$ Figure A.1 shows the evolution of inflation expectations for the EU and other EU membership countries.
} 
show direct evidence that German households' income expectations did not change after the administration announced a change in VAT, and hence income effects cannot explain our results. As for wealth effects, changes in taxes do not change household behavior under Ricardian equivalence. If Ricardian equivalence fails, a tax increase results in a negative wealth effect, which would suggest our design identifies a lower bound of the true effect. Inflation expectations might also affect consumption decisions through a redistribution channel in state-of-the-art heterogeneous-agent models. In section IV, we argue that a sizable redistribution channel is unlikely in our setting.

A concern with our interpretation is households might substitute intratemporally from non-durable to durable consumption, because the VAT change did affect nondurable goods less than durable goods. ${ }^{9}$ We do not observe households' attitudes towards purchases of non-durable goods. To directly address this concern, we show that realized non-durable consumption growth increased slightly during 2006, which is not consistent with intratemporal substitution driving our results.

Using cross-sectional micro data to study the relationship between unconventional fiscal policy, inflation expectations, and willingness to spend has a set of advantages compared to using aggregate time-series data. First, the cross-sectional nature of the data allows us to document the time-varying effects of unconventional fiscal policy on purchasing behavior after the announcement and before the effectiveness of the VAT increase. Second, micro data allow us to control for the changing compositions of populations over time, because of immigration and varying birth rates. These shifts, combined with the heterogeneity in the marginal effect of inflation expectations we document, might result in a spurious correlation between average inflation expectations and average willingness to buy durable goods in the time series.

Our analysis contains a series of caveats. The survey consists of repeated cross sections of households. We cannot exploit within-household variation in inflation expectations to control for time-invariant unobserved heterogeneity at the household level. The rich set of household demographics, the perception of past inflation, household expectations regarding their personal economic outlook (e.g., future personal income), and macroeconomic aggregates (e.g., GDP and unemployment) help alleviate this concern.

\footnotetext{
${ }^{9}$ All services and products in Germany are subject to VAT. The general tax rate was $16 \%$ until December 2006, and increased to $19 \%$ in 2007. A reduced rate of $7 \%$ applies to many convenience goods such as food, books, or flowers. The reduced rate has been unchanged since 1983 .
} 
Moreover, the survey elicits only a measure of households' willingness to purchase consumption goods, and we do not observe the actual consumption behavior of households. In Figure 10, we show households' average willingness to spend closely tracks the actual consumption expenditure on durables. A third potential shortcoming is that the survey elicits only qualitative measures of inflation expectations. However, evidence suggests quantitative inflation expectations bunch at salient threshold values, and households often report large positive and negative inflation expectations (see Binder (2015)). Lastly, prices in Europe are inclusive of VAT, and changes in VAT are salient. A literature on the effect of sales-tax holidays suggests consumers in the United States change their consumption patterns around temporary changes in sales taxes (see Agarwal et al. (2013)). Sales-tax holidays in the United States are typically announced well in advance, for short periods of time, during periods of peak demand such as back-to-school periods, and affect only a small set of goods. The predictability and seasonality of the tax holidays make consumers likely to shift consumption over time. The short time period, often just two or three days, and the small set of goods make assessing the macro implications and ruling out other channels difficult. In addition, the temporary tax cuts reduce tax revenues rather than being budgetary neutral or generating revenues. ${ }^{10}$

We contribute to the recent literature that uses micro-level data to study the relationship between inflation expectations and households' readiness to purchase consumption goods. Bachmann et al. (2015) start this literature using survey data from the Michigan Survey of Consumers (MSC). They find an economically and statistically insignificant association between households' inflation expectations and their readiness to spend on durables. Burke and Ozdagli (2014) confirm these findings using panel data from the New York Fed/RAND-American Life Panel household expectations survey for a period from April 2009 to November 2012. Ichiue and Nishiguchi (2015) show Japanese households that expect higher inflation plan to decrease their future consumption spending. ${ }^{11}$

A large literature estimates the intertemporal elasticity of substitution (IES). Some

\footnotetext{
${ }^{10}$ Note that sales tax holidays can only be stimulative if they are not pre-announced (see Correia et al. (2013)).

${ }^{11}$ Other recent papers using expectations data from the MSC and the New York Fed are Piazzesi and Schneider (2009), Malmendier and Nagel (2009), Dräger and Lamla (2013), Carvalho and Nechio (2014), Coibion and Gorodnichenko (2012), Crump, Eusepi, Tambalotti, and Topa (2015), Kuchler and Zafar (2015), and Armantier, Bruine de Bruin, Topa, Klaauw, and Zafar (2015).
} 
recent papers in this literature use pre-announced tax increases to estimate the IES (see, e.g., Cashin and Unayama (2015)). We do not see our paper as part of this literature, because we focus on purchases of durable goods rather than on the flow consumption of durables. Policy makers care about stimulative effects of inflation expectations, and shocks to inflation expectations might result in large increases in consumption expenditure even with small estimates of the IES. Studies in this literature either use aggregate time-series data, do not observe household expectations or income, cannot distinguish between prices and quantities, or cannot rule out changes in VAT being related to future economic conditions, and therefore cannot disentangle different channels or identify causal effects.

We also relate to Mian and Sufi (2012), who study conventional fiscal policy offering temporary subsidies for the purchases of new cars and document a temporary increase in car sales with a subsequent drop in sales. The car subsidy also changes intertemporal prices, but our paper differs in several ways. We study how a change in VAT, which applies to almost all consumption goods, affects the overall willingness to purchase, as opposed to the purchases of specific items. We show our results operate through intertemporal substitution, whereas the findings in Mian and Sufi (2012) might also operate through an income effect and intratemporal substitution. We also do not find a reversal of the effect after the actual VAT increase, which is consistent with a dynamic, forward-looking Euler equation (see Correia et al. (2013)), whereas the effects in Mian and Sufi (2012) fully revert after a few months. Moreover, the unconventional fiscal policy measure we study, contrary to government subsidies, does not lead to higher budget deficits.

Households with higher inflation expectations are more willing to purchase durable goods in all European countries we study and in periods outside of the VAT experiment, which is consistent with a large theoretical literature that emphasizes the stabilization role of inflation expectations, such as Krugman (1998), Eggertsson and Woodford (2003), Eggertsson (2006), and Werning (2012) on the monetary-policy side and Eggertsson (2011), Christiano, Eichenbaum, and Rebelo (2011), Woodford (2011), and Farhi and Werning (2015) on the fiscal-policy side. From a historical perspective, Romer and Romer (2013) argue deflation expectations caused the Great Depression, whereas Eggertsson (2008) and Jalil and Rua (2015) suggest a fiscal- and monetary-policy mix engineered higher inflation expectations and spurred the recovery from the Great Depression. From an international perspective, Hausman and Wieland (2014) study the monetary 
easing of the Bank of Japan and the expansionary fiscal policy commonly known as "Abenomics." Their time-series evidence is consistent with higher inflation expectations raising consumption and GDP. Pre-announced VAT increases are a salient way to generate future consumer price inflation, and our findings after the announcement and before the effectiveness of a VAT increase might not apply directly to the literature cited above. The salience of consumption taxes could be an advantage of using taxes to generate inflation and to engineer negative real interest rates.

Unconventional monetary policy such as forward guidance aims to generate inflation expectations today through future government purchases or low interest rates until after the end of the liquidity trap. Bachmann et al. (2015) question the effectiveness of these policies, because they do not find any association between inflation expectations and consumption propensities. Dupor and Li (2015) do not find evidence consistent with government purchases stimulating inflation expectations. Del Negro, Giannoni, and Patterson (2015) and McKay, Nakamura, and Steinsson (2015) empirically and theoretically question the power of forward guidance. Unconventional fiscal policies might therefore be a suitable alternative to unconventional monetary policy and conventional fiscal policy in light of these findings, especially during periods of large government budget deficits and inflated central bank balance sheets.

\section{Data}

\section{A. Data Sources}

We use the confidential micro data underlying the GfK Consumer Climate MAXX survey. GfK conducts the survey on behalf of the Directorate General for Economic and Financial Affairs (DG ECFIN) of the European Commission. ${ }^{12}$ GfK monthly asks a representative repeated cross section of 2,000 German households questions about general and personal economic conditions, inflation expectations, and willingness to spend on consumption goods. We obtained access to the micro data for the period starting in January 2000 and ending in December 2013. Our sample period includes large variation in macroeconomic fundamentals, two major recessions, and an unexpected increase in German VAT in 2007.

\footnotetext{
${ }^{12}$ We use similar data from the harmonized surveys of DG ECFIN for several other European countries in section IV. We discuss the data in more detail in the online appendix.
} 
We use the answers to the following two questions in the survey to construct the main variables in our baseline analysis:

Question 8 Given the current economic situation, do you think it's a good time to buy larger items such as furniture, electronic items, etc.?

Households can answer, "It's neither a good nor a bad time," "No, it's a bad time," or "Yes, it's a good time."

Question 3 How will consumer prices evolve during the next twelve months compared to the previous twelve months?

Households can answer, "Prices will increase more," "Prices will increase by the same," "Prices will increase less," "Prices will stay the same," or "Prices will decrease." We create a dummy variable that equals 1 when households answer, "Prices will increase more," to get a measure of higher expected inflation. ${ }^{13}$

Households' inflation expectations are highly correlated with their perception of past inflation (see Jonung (1981)). We also use survey question 2 in our baseline analysis to disentangle the effects of inflation expectations from inflation perceptions:

Question 2 What is your perception on how consumer prices evolved during the last twelve months?

Households can answer, "Prices increased substantially," "Prices increased somewhat," "Prices increased slightly," "Prices remained about the same," or "Prices decreased."

The online appendix contains the original survey and a translation to English.

We also use questions regarding expectations about general economic variables, personal income or unemployment, and a rich set of socio-demographics from the GfK survey. In robustness checks, we use data on contemporaneous macroeconomic aggregates, such as GDP and unemployment numbers from the German statistical office (DeStatis), nominal interest rates, the value of the German stock index DAX, and measures of European and German policy uncertainty from Baker, Bloom, and Davis (2014). The online appendix describes in detail the data sources and variable definitions.

\footnotetext{
${ }^{13}$ Results do not change if we introduce separate dummies for the individual answer possibilities (see Table 3 in the online appendix).
} 


\section{B. Descriptive Statistics}

Table 1 contains some basic descriptive statistics. On average, $20 \%$ of households say it is a good time to buy durables, $24 \%$ say it is a bad time, and the others are indifferent. Fourteen percent of households expect higher inflation in the following 12 months. More than $80 \%$ of respondents think prices in the previous 12 months increased substantially, somewhat, or slightly, with equal proportions for each answer. Only 13\% think prices remained the same, and essentially nobody thinks prices decreased.

The sample is balanced between women and men. Most respondents completed high school, but have no college education. ${ }^{14}$ The mean household's size is 2.5 , and the majority of households live in cities with fewer than 50,000 inhabitants.

Panel C of Table 1 reports statistics for households' personal expectations. Most households think their financial situation has not changed in the previous 12 months, and they expect the same for the future. Most households do not save or save only a little, and expect a constant or slightly increasing unemployment rate. Panel D of Table 1 describes macroeconomic aggregates. The inflation rate averaged around $1.6 \%$ per year, and the average unemployment rate was slightly below $8 \%$. The average level of the DAX stock index was 5,840 points, with an average annual volatility of $22.79 \%$. Industrial production grew about $1.6 \%$ per year, and the average oil price was $\$ 63$.

Figure 2 is a time-series plot of the fraction of households that expect higher inflation, and of the average willingness to buy durable goods. Higher values correspond to a higher propensity to spend. Expected inflation increases hover around the time-series mean at the beginning of the sample, and then spike in 2001 before dropping and staying below the mean until 2005. A sharp increase in expected inflation occurs in 2006, with a subsequent drop and two minor spikes in mid-2007 and 2008. The series fluctuates around its mean for the rest of the sample. The propensity to purchase durables drops below the mean in 2002. The series increases slightly before a sharp increase in 2006. The increase reverts in 2007. The series starts trending upward at the end of 2008.

Actual inflation increases in January 2007, but peaks later in the year. Anecdotal evidence suggests many retailers delayed price increases because they feared a stark drop

\footnotetext{
${ }^{14}$ Most respondents completed either Hauptschule or Realschule, and only $8 \%$ of respondents have a college degree.
} 
in demand. ${ }^{15}$ The German statistical office shows some categories immediately and fully adjusted prices, such as tobacco and services, whereas other categories adjusted prices with a delay, such as electronics and furniture. By early 2008 all categories underlying the German CPI had fully adjusted their prices by the theoretical amount. ${ }^{16}$

We discuss in detail in section $\mathrm{V}$ the relation between inflation expectations and actual inflation, willingness to purchase durables, and actual purchases.

\section{Baseline Analysis}

To test for an effect of unconventional fiscal policy on purchasing propensities via an inflation-expectations channel, we first have to verify that households' willingness to purchase reacts to changes in inflation expectations.

In this section, we document a positive association between households' inflation expectations and their willingness to purchase durable goods over time and across countries.

\section{A. Econometric Model}

Our outcome variable of interest, households' readiness to purchase durable goods, derives from discrete, non-ordered choices in a survey. We therefore model the response probabilities in a multinomial-logit setting.

We assume the answer to the question on the readiness to spend is a random variable representing the underlying population. The random variable may take three values, $y \in\{0,1,2\}: 0$ denotes it is neither a good nor a bad time to purchase durable goods; 1 denotes it is a bad time to purchase durable goods; and 2 denotes it is a good time to purchase durable goods.

We define the response probabilities as $P(y=t \mid X)$, where $t=0,1,2$, and $X$ is an $N \times K$ vector where $N$ is the number of survey participants. The first element of $X$ is a unit vector, and the other $K-1$ columns represent a rich set of household-level observables, including demographics and expectations. The set of observables $X$ allows

\footnotetext{
${ }^{15}$ See: http://www.handelsblatt.com/politik/deutschland/staatsdefizit-unter-drei-prozent-deutschesdefizitverfahren-wird-eingestellt/2754740.html. We thank Emi Nakamura for emphasizing this point.

${ }^{16}$ See: https://www.destatis.de/DE/Publikationen/WirtschaftStatistik/Preise/MwSterhoehungJan2007.pdf.
} 
us to control for heterogeneity across households in purchasing propensities, which may be correlated with inflation expectations.

We assume the distribution of the response probabilities is

$$
P(y=t \mid X)=\frac{e^{X \beta_{t}}}{1+\sum_{z=1,2} e^{X \beta_{z}}}
$$

for $t=1,2$, and $\beta_{t}$ is a $K \times 1$ vector of coefficients. The response probability for the case $y=0$ is determined, because the three probabilities must sum to unity

$$
P(y=0 \mid X)=\frac{1}{1+\sum_{z=1,2} e^{X \beta_{z}}} .
$$

We estimate the model via maximum likelihood to obtain the vector $\beta_{t}$ of coefficients for $t=1,2$, and set the category $y=0$ as the baseline response.

We compute the marginal effects of changes in the covariates on the probability that households choose any of three answers in the survey.

For approximately continuous covariates, we can compute the marginal effect of each covariate $x$ on the response probability as the derivative of $P(y=t \mid x)$ with respect to $x$ :

$$
\frac{\partial P(y=t \mid x)}{\partial x}=P(y=t \mid x)\left[\beta_{t x}-\sum_{z=0,1,2} P(y=z \mid x) \beta_{z x}\right]
$$

for $z=0,1,2$. For discrete covariates, we calculate marginal effects by predicting the response probabilities for the potential values of the covariates, and compute the average across predicted probabilities.

\section{B. Baseline Estimation}

Table 2 reports the average marginal effects computed from the multinomial logit regressions. We cluster standard errors at the quarter level (56 clusters) to allow for correlation of unknown form in residuals across contiguous months. In all columns, we report the marginal effect of the inflation-increase dummy on the likelihood that households respond that it's a good time to buy durables. In column (1), the inflation-increase dummy is the only explanatory variable. Households that expect increasing inflation over the following 12 months are on average $6.2 \%$ more likely to answer 
that it's a good time to buy durables compared to households that expect constant or decreasing inflation.

Perceptions of past inflation shape households' expectations about future inflation (Jonung (1981)). Controlling for past inflation perceptions increases the marginal effect of inflation expectations on the willingness to buy durables (see column (2)). High perceptions of past inflation decrease the marginal propensity to consume durables, consistent with the consumption Euler equation.

Households differ in their purchasing propensity (see, e.g., Attanasio and Weber (1993)). Household characteristics that determine both purchasing propensities and inflation expectations might be systematically related, and hence controlling for the observed heterogeneity across households is important. In columns (3)-(5) of Table 2, we add a rich set of demographics, expectations about personal and macroeconomic variables, and contemporaneous macroeconomic variables. Adding demographics has little impact on the statistical significance and economic magnitude of the effect of higher inflation expectations on the willingness to purchase durables (column (3)). Controlling for households' expectations regarding their own prospects or future macroeconomic variables (column (4)) increases the marginal effect of the inflation-increase dummy on the willingness to purchase durables. Households that expect higher inflation are on average $8.9 \%$ more likely to have positive spending attitudes compared to households that expect constant or decreasing inflation. Adding contemporaneous macroeconomic variables in column (5) does not affect these findings. All marginal effects are virtually identical if we do not condition on past inflation.

Economically, a back-of-the-envelope calculation implies the marginal effect of inflation expectations on the willingness to buy durables translates into $4.8 \%$ higher real durable consumption expenditure if all Germans expect higher inflation. To reach this suggestive conclusion, we regress the natural logarithm of real durable consumption expenditure at the quarterly frequency on the end-of-quarter value of the average durable purchasing propensity and quarterly dummies, and multiply the resulting coefficient of 0.5396 by the marginal effect of $8.88 \%$ (column (4) of Table 2). 


\section{Heterogeneity of the Effect}

Table 2 shows household heterogeneity is potentially important for the marginal effect of inflation expectations on purchasing propensities. We have to take these potential differences across demographics into account when we construct our control group in section IV.

Table 3 studies the variation in the baseline effect by household characteristics. We first consider respondents' education. Germany has a three-tier school system, and pupils choose their secondary education track after four years of primary school. Hauptschule offers a total of 9 years of basic education, Realschule offers 10 years, and Gymnasium offers 13 years, concluding with A levels (required to enter college). Columns (1)-(2) of Table 3 report the marginal effects for our baseline specification estimated separately for survey participants with a Hauptschule degree and those with college education. Households with low levels of education that expect inflation to increase are $6.9 \%$ more likely to have a positive stance toward buying durables compared to households that expect constant or decreasing inflation (column (1)). This marginal effect increases with education, and is more than $60 \%$ larger for household heads that hold a college degree (column (2)).

Moving on to households' income, we find a $20 \%$ higher marginal effect of inflation expectations on the likelihood of wealthier survey participants with a monthly net income above EUR 2,500 replying that it's a good time to buy durables (column (4)), compared to survey participants with less than EUR 1,000 monthly net income (column (3)).

Lifetime inflation experiences matter for how recent inflation shapes inflation expectations of young and old households (see Malmendier and Nagel (2009)). Retirees have different time-use and consumption patterns compared to the working-age population (see Aguiar and Hurst (2005)), and typically have nominal pensions in Germany, hold few real assets, and have lower human capital compared to someone in the labor force. The marginal effect of inflation increases on the willingness to spend is lower for those aged 65 or higher (column (6)) than for the younger population (column (5)).

The analysis unveils substantial heterogeneity in the marginal effect of higher inflation expectations on the purchasing propensities of households. We will therefore account for this heterogeneity in the identification strategy of section IV, which matches German households with observationally equivalent foreign households, using a nearest-neighbor 
matching procedure based on households' demographics.

\section{Natural Experiment and Identification Strategy}

\section{A. Exogenous Unconventional Fiscal-Policy Measure}

Our aim is to test for the causal effect of unconventional fiscal-policy measures on households' willingness to purchase durable goods through higher inflation expectations. To reach this aim, we need an exogenous fiscal-policy shock that affected households' inflation expectations, and did not affect households' willingness to purchase durable goods through other channels. We attempt to get close to such an ideal fiscal-policy shock following a narrative approach (see Romer and Romer (2010)).

In November 2005, the newly-formed German government unexpectedly announced a three-percentage-point increase in the VAT, effective January 2007. The narrative record suggests the VAT increase was legislated for reasons unrelated to future economic conditions. Instead, the increase was mandated to reduce German's budget deficit as a fraction of GDP below a threshold of 3\%. The Maastricht Treaty of 1992 requires all EU countries to have "annual deficits no greater than $3 \%$ of GDP." The then-conservative German administration was the major sponsor of the budget and deficit rules, and first proposed sounds fiscal policies as a central pillar of the Maastricht Treaty.

In each of the four years during the 2001-2004 period , Germany posted a deficitto-GDP ratio above 3\%. In 2003, the European Commission opened a procedure against Germany for infringement of the 3\% deficit-to-GDP rule. The German administration proposed plans to reduce the ratio to $2.9 \%$ in 2005 to avoid fines. It became obvious during 2005 that Germany could not deliver on their promises. The actual deficit-to-GDP ratio was $3.3 \%$ for 2005. The European Commission re-opened the deficit procedure and announced in November of 2005 that it would fine Germany if the ratio was not below 3\% by the end of 2007. The newly elected right-left government announced in November 2005 that it would increase the VAT by three percentage points from $16 \%$ to $19 \%$, effective in January 2007.

Therefore, the increase in VAT was unrelated to future economic conditions of Germany, and it was adopted to satisfy the requirements of the EU Stability and Growth 
Pact. ${ }^{17}$ Based on these reasons, we argue the VAT increase falls within the exogenous tax-change category following the taxonomy of Romer and Romer (2010).

A pre-announced VAT increase in a fixed-nominal-rates environment resembles the unconventional fiscal policies to stimulate spending through higher inflation expectations described in Correia et al. (2013). Feldstein (2002) proposes pre-announced VAT increases mechanically to generate higher future inflation and incentivize households to frontload consumption expenditure. Hall and Woodward (2008) argue along similar lines for sales-tax holidays to generate an increasing path of consumption taxes over time and stimulate current spending. Hall (2011) emphasizes the use of consumption taxes to alter intertemporal prices.

The announcement of the VAT increase is a shock to inflation expectations, and should result in higher consumption expenditure as long as nominal interest rates do not increase sufficiently to leave real rates constant. Germany is part of the euro area, and the ECB is responsible for monetary policy and price stability in the whole currency area. The ECB did not tighten monetary policy to counteract the increase in inflation expectations in Germany. Nominal borrowing rates for consumption loans were $6.7 \%$ in January 2006 and 6.4\% in December 2007.

The VAT increase in January 2007 should result in higher inflation expectations of German households throughout 2006. Figure 3 shows German households started to adjust their inflation expectations upwards immediately in January 2006. Inflation expectations remained high for the rest of 2006, and reverted once the VAT increase was in effect in January 2007. Realized inflation started to increase in January of 2007, and remained high throughout year.

\section{B. Difference-in-Differences Approach}

The VAT shock alone does not allow a causal test for the effect of inflation expectations on consumption expenditures, because all German households were exposed to the same shock. For identification, we miss a counterfactual: a group of households not affected by the shock, but similar to German households based on observables before the shock.

The European Commission conducts harmonized surveys in all EU countries.

\footnotetext{
${ }^{17}$ We discuss in more detail the narrative sources, the scope of the VAT increase, and the relation between future VAT increases and inflation expectations in section V.
} 
We obtained access to the confidential micro data for three additional countries (France, Sweden, and the United Kingdom) through national statistical offices and GfK subsidiaries. ${ }^{18}$ We use the households in these three countries to construct our control group.

Our identification strategy is a difference-in-differences approach: we compare German households' readiness to purchase durables with that of households in other European countries, before and after the VAT shock.

We estimate the average treatment effect (ATE) of the VAT shock on the readiness to purchase durables as

$$
\left(\overline{D u r}_{\text {German, post }}-\overline{\operatorname{Dur}}_{\text {German, pre }}\right)-\left(\overline{\text { Dur }}_{\text {foreign, post }}-\overline{\text { Dur }}_{\text {foreign, pre }}\right),
$$

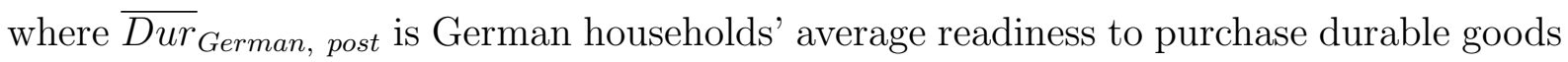

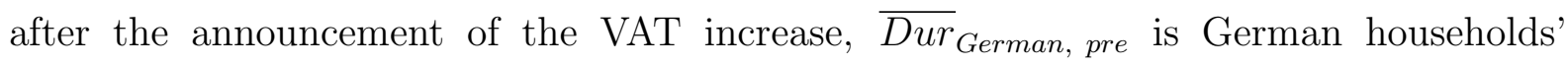
average readiness to purchase durables goods before the announcement of the VAT increase, and $\overline{D u r}_{\text {foreign, post }}$ and $\bar{D}_{\text {Dur }}$ foreign, pre are the analogous averages for foreign households not exposed to the VAT shock.

\section{Identifying Assumptions}

The parallel-trends assumption is a necessary condition for identification. It requires our control group to behave similarly to German households before the announcement of the VAT increase. Under this assumption, we can interpret the evolution of inflation expectations and consumption behavior of matched foreign households after the announcement as a valid counterfactual to the evolution of the behavior of German households absent the VAT shock.

The top panels of Figure 4 and Figure 5 provide graphical evidence that the paralleltrend assumption seems satisfied in our setting. The trends in inflation expectations and purchasing propensities are parallel for German and foreign households before the announcement of the VAT increase (November 2005). Starting in January 2006, both the German households' inflation expectations and willingness to buy durable goods start to increase substantially. Trends for foreign households do not move compared to the

\footnotetext{
${ }^{18}$ The online appendix contains details of the data sources and the surveys used in the national language.
} 
pre-shock period. The middle panels of Figure 4 and Figure 5 repeat the exercise when comparing German households to French households only. France and Germany face the same monetary policy, share a common border, and are structurally similar. The similarity of pre-shock trends is even more pronounced when we only use French households as a control group. In the bottom panels of Figure 4 and Figure 5, we also compare the trends for German households and for households in the UK and Sweden. Cavallo, Neiman, and Rigobon (2014) show firms within the euro area harmonize prices of durable goods. ${ }^{19}$ Even in this case, the parallel-trends assumption seems plausible.

Importantly, Table 4 verifies households in each of the three foreign countries display a positive association between inflation expectations and willingness to consume durable goods (columns (1)-(3)). In column (4), we report the corresponding baseline effect for German households, excluding the period after the announcement of the VAT increase and before the actual increase. The size of the association between inflation expectations and consumption propensities is similar to the size of the association for households in France, Sweden, and the UK. Foreign households are therefore likely to react to increases in inflation expectations in a similar fashion as German households, which alleviates the concerns regarding the external validity of our identification.

\section{Matching Foreign and German Households}

Foreign households seem a valid counterfactual to the behavior of German households. We match households in Germany with households abroad to account for the heterogeneity in responsiveness to inflation expectations. We first match each German household in each month with a household in another country, interviewed in the same month, with similar demographic characteristics. We use a nearest-neighbor algorithm to match households based on propensity scores. ${ }^{20}$ We estimate propensity scores with a logit regression of the treatment indicator on gender, age, education, income, and social status. Our samples are repeated cross sections, and we cannot track German and matched foreign households before and after the shock. We perform a second level of matching, which pairs up similar households interviewed before and after the shock separately within the German and the

\footnotetext{
${ }^{19}$ We thank Brent Neiman for suggesting this test.

${ }^{20}$ All the results are virtually identical if we perform the monthly matching using a group of control households for each German household, and we minimize the difference in observables of the German household and the group of foreign households.
} 
foreign survey waves.

The matching exercise is meaningful only for German and foreign households in the common support of the distributions of the propensity score for the two groups. In Figure 6 , we plot the distribution of the propensity score for the treatment group (red) and the control group (blue). Households are distributed across the full range of the propensity score in both groups.

Moreover, we formally test whether households' characteristics are balanced after the matching process. In Table 5, we report the mean of the matching categories for households in the control group and treated group as of June 2005, our baseline month before the announcement of the VAT increase. Columns (3) and (4) test the null hypothesis that the means across the two groups are equal. We cannot reject the null for any of the five matching variables.

All our results are similar or become stronger if we only use households from France as a control group. Using a larger pool of control households increases the size of the common support, and improves the balancing of matched households' characteristics ex post.

\section{E. Threats to Identification}

Changes in VAT might affect households' decisions to purchase durables through channels different from inflation expectations. A positive average treatment effect in equation (4) might reflect those other channels, in which case we could interpret our finding only as an impulse response of consumption expenditure to the announcement of a VAT increase, as opposed to the causal effect of unconventional fiscal policy on consumption expenditure through inflation expectations. We test below whether the VAT shock affected households' expectations other than inflation expectations, which might affect the readiness to spend on durables irrespective of inflation expectations.

In a neoclassical representative agent model, the change in VAT could affect the consumption behavior of Germans through income and wealth effects rather than intertemporal substitution. The increase in VAT might lead households to adjust their income expectations upward. Figure 7 plots the evolution of average income perceptions and income expectations over the next 12 months together with inflation expectations. The announcement of the VAT increase does immediately increase average inflation 
expectations, whereas the average perception of income and the average expectation of future income do not move.

The announced change in VAT should not alter the behavior of German households through wealth effects in a Ricardian world. If Ricardian equivalence does not hold, an increase in VAT should result in a negative wealth effect and lower consumption expenditure. We would identify a lower bound of the causal effect in such a world.

Modern heterogeneous-agent models prominently feature a redistribution channel of surprise inflation from lenders to borrowers (see Doepke and Schneider (2006)). Under the assumptions of all goods being subject to the higher VAT and $100 \%$ tax incidence on the consumer side, we would expect an increase in consumer price inflation of $2.59 \%$. However, the change in inflation is only a surprise for loan contracts that existed in November of 2005 and matured after December 2006. For this subset of contracts, we do expect a redistribution of nominal wealth from lenders to borrowers. At the same time, the increase in VAT was permanent and should result in a reduction in wealth corresponding to $2.59 \%$ of lifetime consumption under the assumption that consumers do not change their consumption bundle after the VAT announcement. The net wealth effect of an increase in VAT is therefore most likely negative for both borrowers and lenders and we would again identify a lower bound.

More elaborate models with financial constraints or hand-to-mouth consumers might offer alternative channels. We cannot test for all alternative channels with our data. However, financial constraints or hand-to-mouths behavior are unlikely to drive our findings, because tax increases should result in lower consumption expenditure in these alternative models.

An intratemporal substitution from non-durable to durable consumption without increasing overall consumption might be another alternative channel we want to discuss. Figure 8 plots the real durable and non-durable consumption growth at the quarterly frequency. Real durable consumption growth increases sharply during 2006. However, non-durable consumption growth also increases and is beyond historical averages during this period. Table A.2 in the online appendix shows that households expecting higher inflation are also less likely to save compared to households with constant or decreasing inflation expectations. Both sets of results make an intratemporal substitution channel driving our findings unlikely. 


\section{F. Causal Effect of VAT Shock on Willingness to Buy Durables}

We run a set of cross-sectional regressions on the matched sample before and after the announcement of the VAT increase to estimate the average treatment effect of the VAT shock in equation (4). We set the reference month to June 2005, and we change the end month $m$ across regressions. ${ }^{21}$

We estimate the following specification:

$$
\Delta \operatorname{Dur}_{i, 06 / 2005 \rightarrow m}=\alpha+\beta_{m} \times V A T \text { shock }_{i}+\Delta X_{i, 06 / 2005 \rightarrow m}^{\prime} \times \gamma+\epsilon_{i},
$$

where $\Delta D u r_{i, 06 / 2005 \rightarrow m}$ is the difference in the willingness to spend on durable goods between month $m$ and June 2005, VATshock $k_{i}$ is an indicator equal to 1 if the household was exposed to the VAT shock, $\beta_{m}$ captures the effect of the VAT shock on household $i$ 's willingness to buy durables in month $m$, and $\Delta X_{i, 06 / 2005 \rightarrow m}^{\prime}$ is the difference in a set of observables between month $m$ and the baseline month.

Figure 9 plots the estimated coefficient $\hat{\beta}_{m}$ (solid line) of equation (5) for each month $m$ from July 2005 to December 2007, and the 95\% confidence intervals (dashed line). We find no difference in the readiness to spend on durable goods between German and matched households before the announcement of the VAT increase. Starting in December 2005, the VAT shock results in a positive effect on the willingness of German households to purchase compared to matched households: German households are 3.8 percentage points (s.e. 1.5 percentage points) more likely to declare that it is a good time to purchase durable goods after the announcement compared to before, and compared to matched foreign households. The effect increases in magnitude throughout 2006 and peaks at 34 percentage points in November 2006. The average treatment effect drops to zero in January 2007 once VAT increases and higher inflation materializes. ${ }^{22}$

Figure 9 shows the VAT shock has a strong and positive effect on the willingness of German households to purchase durable goods after the announcement and before the increase took effect, even after controlling for the purchasing propensities of similar households not exposed to the shock in a difference-in-differences setting. We do not

\footnotetext{
${ }^{21}$ All the results are similar if we use any other month before the announcement of the VAT increase in November 2005.

${ }^{22}$ Figure A.2 in the online appendix plots the average treatment effect of a specification in which we match on income expectations for the next 12 months in addition to gender, age, education, income, and social status. Results are virtually identical.
} 
detect any reversal of the positive effect of the VAT shock on the willingness to purchase durable goods after January 2007, which is consistent with the consumption behavior in a dynamic, forward-looking Euler equation (see Correia et al. (2013)).

\section{Discussion}

In this section, we describe in detail the narrative records surrounding the 2005 general elections in Germany, and the relationship between willingness to spend and actual spending, inflation expectations and actual inflation, and reduced and full VAT.

2005 electoral campaign platforms and election outcome: The Christian Democrats (CDU, center-right) were the only German party in the 2005 electoral campaign advocating an increase in VAT by $2 \%$ starting in January 2006 to lower non-wage labor costs (see CDU (2005), page 14). The Social Democrats (SPD, center-left) strongly opposed an increase in VAT, and instead favored a $3 \%$ increase in income tax for top income earners (see SPD (2005), page 39). The Greens (center-left) and Liberals (center-right) also strongly opposed an increase in VAT. The Liberals, for example, promised to decrease the general tax burden by EUR $19 \mathrm{bn}$.

All parties except the CDU strongly opposed raising VAT, including CDU's preferred coalition partner, the Liberals. The projections of the election outcomes were highly uncertain (see below), as well as the fiscal policy measures the new administration would have implemented. A VAT increase of $3 \%$ was therefore highly unexpected. Consistently, the opposition parties and the popular press accused the new administration between CDU and SPD of electoral fraud after they announced this policy measure in November 2005, and they fiercely criticized the new administration. The online appendix contains press clippings commenting on the VAT policy (see section III of the online appendix).

Figure 2 is direct evidence that German households did not expect an increase in VAT in 2006, as the CDU proposed: households' inflation expectation over the next 12 months did not increase until January 2006, after the new administration had announced its plans in November 2005 to increase VAT in 2007, rather than 2006 as the CDU had planned initially. ${ }^{23}$

\footnotetext{
${ }^{23}$ If voters had considered the CDU proposal credible, we should already see an increase in inflation expectation during the campaign in the summer of 2005, because the plan was to increase VAT in January 2006.
} 
Neither of the two blocks - CDU and Liberals on the one hand, and SPD and Greens on the other hand-had a majority in polls before the elections. ${ }^{24}$ In the actual election on September 18, 2005, the CDU gained 35.2\% electoral support; the SPD, $34.2 \%$; the Liberals, 9.8\%; the Left, 8.7\%; and the Greens, 8.1\%. Neither the CDU nor the SPD were able to form a "small" coalition with their preferred coalition partner (Liberals and Greens, respectively). The CDU and SPD therefore agreed to form a "grand" coalition.

The coalition agreed on an overall contractionary fiscal policy (see below), including the increase of VAT by 3\%, and the use of one third of the additional tax revenue to decrease non-wage labor costs. The administration planned to use two thirds of the VAT increase to consolidate the federal budget to comply with the Maastricht Treaty and hinder an infringement procedure by the European Commission. Table A.3 in the online appendix shows the total tax revenue indeed increased in 2007, and Germany no longer violated the EU Stability and Growth Pact.

Other Policy Measures: The new administration announced additional policy measures as part of its coalition agreement. The preamble of the official agreement emphasizes the need to reduce Germany's public debt as the major challenge for the new administration, and that the set of agreed policy measures would be contractionary overall. In addition to the VAT increase and the non-wage labor-costs reduction mentioned above, the administration announced an investment program of $0.25 \%$ of 2005 GDP per year over the following four years. The administration planned to finance the majority of the program through budget cuts. Moreover, the administration announced an increase in the top marginal income tax rate from $42 \%$ to $45 \%$ for incomes above EUR 250,000 for singles and EUR 500,000 for couples. Lastly, the administration planned to increase indirect taxes for retirement from $19.4 \%$ to $19.9 \%$, and it abolished the home-buyer subsidy, which had been guaranteed since 1949, and amounted to EUR 11.4 billion in $2004 .^{25}$ The overall contractionary nature of this set of policies suggests our estimates in section IV represent a lower bound of the positive effect of the announcement to increase

\footnotetext{
${ }^{24}$ Eleven days before the elections, the polling institute Infratest Dimap predicted a vote share of $41 \%$ for the CDU, $34 \%$ for the SPD, $8.5 \%$ for the Left, $7 \%$ for the Greens, and $6.5 \%$ for the Liberals. See http://www.infratest-dimap.de/en/umfragen-analysen/bundesweit/sonntagsfrage/. All parties explicitly ruled out any coalition with the Left. The media mentioned alll other possible combinations, including non-traditional combinations, as possible coalitions, including a "traffic-light" coalition between SPD, Greens, and Liberals and a "Jamaica" coalition between CDU, Liberals, and Greens.

${ }^{25}$ See http://www.kas.de/upload/ACDP/CDU/Koalitionsvertraege/Koalitionsvertrag2005.pdf for details.
} 
VAT in 2007 on households' willingness to purchase durables.

Willingness to spend versus actual spending: We are ultimately interested in how inflation expectations transform into actual consumption. Our survey only reports the willingness to purchase durable goods. Figure 10 is a scatter plot of the cyclical components of log real durable consumption and the average propensity to purchase durables. ${ }^{26}$ Real and reported spending on durables are positively related with a correlation of 0.46 .

The reported willingness to purchase has potential advantages compared to measures of actual expenditures elicited with surveys. Spending data in surveys typically contain noise, because survey participants might not recall their actual purchases, or they might overstate their purchases of visible products such as cars and understate the consumption of "sin" products, such as tobacco and alcohol (see Hurd and Rohwedder (2012) and Atkinson and Micklewright (1983)).

Reduced and full VAT tax: All services and products in Germany are subject to a value-added tax that is part of the European VAT system. The general tax rate was 16\% until December 2006 and increased to $19 \%$ in 2007. A reduced rate of $7 \%$ applies to many convenience goods such as food, books, or flowers. The reduced rate has been unchanged since 1983. Rent, services for non-profit organizations, and medical expenses are not subject to VAT. Virtually all durable goods are subject to the full VAT, whereas only $59 \%$ of non-durables are subject to a VAT rate of $19 \%$.

\section{Concluding Remarks}

We propose a causal test for the effect of unconventional fiscal policies on households' consumption attitudes. We test for the effect of a pre-announced increase in value added tax (VAT) on the willingness of households to buy durable goods, through an inflationexpectations channel.

The natural experiment we exploit for identification - an unexpected announcement in 2005 to increase German VAT in 2007-is unique in that the expectations of the German administration regarding future economic conditions did not trigger it. The EU imposed it to comply with its budgetary requirements. Moreover, the European Central

\footnotetext{
${ }^{26}$ We use a Hodrick-Prescott filter with smoothing parameter $\lambda$ of 1,600 to extract the cyclical component.
} 
Bank explicitly stated it would not increase nominal interest rates to combat an expected increase in inflation, which they considered temporary and locally confined.

We use observationally similar households in other European countries not exposed to the VAT shock as a counterfactual in a difference-in-differences identification design.

The announcement of an increase in VAT led to an increase in German households' inflation expectations and in their willingness to buy durable goods, compared to households in other European countries exposed to the same macroeconomic environment but not exposed to the VAT shock. The announcement did not change households' expectations regarding future income, suggesting income effects do not drive our findings. We find an intratemporal substitution channel from non-durable to durable goods, wealth effects, or redistribution through inflation unlikely explanations for the effect of the VAT shock on spending attitudes.

Our results suggest budget-neutral unconventional fiscal policies can be a viable alternative to unconventional monetary and conventional fiscal policy to stimulate aggregate demand, especially in times of large government budget deficits and inflated central bank balance sheets.

We also document a stable, positive cross-sectional association between households' inflation expectations and their willingness to purchase durable consumption goods outside of the VAT announcement period, and across all European countries in our data set. This association is robust over time, suggesting households act on their inflation expectations when making consumption decisions. The size of this positive association varies substantially in the cross section of households, based on their demographics: more educated, higher income, and younger households display a more positive association between inflation expectations and the willingness to buy durable goods. 


\section{References}

Agarwal, S., N. Marwell, and L. McGranahan (2013). Consumption responses to temporary tax incentives: Evidence from state sales holidays. Unpublished Manuscript, University of Wisconsin.

Aguiar, M. and E. Hurst (2005). Consumption versus expenditure. Journal of Political Economy 113(5), 919-948.

Armantier, O., W. Bruine de Bruin, G. Topa, W. Klaauw, and B. Zafar (2015). Inflation expectations and behavior: Do survey respondents act on their beliefs? International Economic Review 56(2), 505-536.

Atkinson, A. B. and J. Micklewright (1983). On the reliability of income data in the family expenditure survey 1970-1977. Journal of the Royal Statistical Society. Series A (General) 146(1), 33-61.

Attanasio, O. P. and G. Weber (1993). Consumption growth, the interest rate and aggregation. The Review of Economic Studies 60(3), 631-649.

Bachmann, R., T. O. Berg, and E. Sims (2015). Inflation expectations and readiness to spend: cross-sectional evidence. American Economic Journal: Economic Policy 7(1), $1-35$.

Baker, S. R., N. Bloom, and S. J. Davis (2014). Measuring economic policy uncertainty. Unpublished Manuscript, Stanford University.

Barro, R. J. and C. J. Redlick (2011). Macroeconomic effects from government purchases and taxes. The Quarterly Journal of Economics 126(1), 51-102.

Binder, C. (2015). Consumer inflation uncertainty and the macroeconomy: evidence from a new micro-level measure. Unpublished Manuscript, UC Berkeley.

Burke, M. A. and A. Ozdagli (2014). Household inflation expectations and consumer spending: evidence from panel data. Unpublished Manuscript, Federal Reserve Bank of Boston 13(25), 1-43.

Caballero, R. J., E. Farhi, and P.-O. Gourinchas (2015). Global imbalances and currency wars at the ZLB. Technical report, National Bureau of Economic Research.

Carvalho, C. and F. Nechio (2014). Do people understand monetary policy? Journal of Monetary Economics 66, 108-123.

Cashin, D. and T. Unayama (2015). Measuring intertemporal substitution in consumption: evidence from a VAT increase in Japan. Review of Economics and Statistics (forthcoming).

Cavallo, A., B. Neiman, and R. Rigobon (2014). Currency unions, product introductions, and the real exchange rate. The Quarterly Journal of Economics 129(2), 529-595.

CDU (2005). Deutschlands Chancen nutzen. Wachstum. Arbeit. Sicherheit. Electoral Manifest.

Christiano, L., M. Eichenbaum, and S. Rebelo (2011). When is the government spending multiplier large? Journal of Political Economy 119(1), 78-121.

Coibion, O. and Y. Gorodnichenko (2012). What can survey forecasts tell us about information rigidities? Journal of Political Economy 120(1), 116-159.

Correia, I., E. Farhi, J. P. Nicolini, and P. Teles (2013). Unconventional fiscal policy at the zero bound. American Economic Review 103(4), 1172-1211.

Crump, R. K., S. Eusepi, A. Tambalotti, and G. Topa (2015). Subjective intertemporal substitution. FRB of New York Staff Report (734).

Del Negro, M., M. P. Giannoni, and C. Patterson (2015). The forward guidance puzzle. FRB of New York Staff Report (574).

Doepke, M. and M. Schneider (2006). Inflation and the redistribution of nominal wealth. 
Journal of Political Economy 114(6), 1069-1097.

Dräger, L. and M. J. Lamla (2013). Anchoring of consumers' inflation expectations: Evidence from microdata. Unpublished Manuscript, University of Hamburg.

Dupor, B. and R. Li (2015). The expected inflation channel of government spending in the postwar U.S. European Economic Review 74, 36-56.

Eggertsson, G. B. (2006). The deflation bias and committing to being irresponsible. Journal of Money, Credit and Banking 38(2), 283-321.

Eggertsson, G. B. (2008). Great expectations and the end of the depression. The American Economic Review 98(4), 1476-1516.

Eggertsson, G. B. (2011). What fiscal policy is effective at zero interest rates? In NBER Macroeconomics Annual 2010, Volume 25, pp. 59-112. University of Chicago Press.

Eggertsson, G. B. and M. Woodford (2003). The zero bound on interest rates and optimal monetary policy. Brookings Papers on Economic Activity 2003(1), 139-211.

Farhi, E. and I. Werning (2015). Fiscal multipliers: Liquidity traps and currency unions. Unpublished Manuscript, MIT.

Feldstein, M. (2002). The role for discretionary fiscal policy in a low interest rate environment. Technical report, National Bureau of Economic Research.

Hall, R. and S. Woodward (2008, December 11). Measuring the effect of infrastructure spending on GDP, Financial Crisis and Recession (blog).

Hall, R. E. (2011). The long slump. American Economic Review 101 (2), 431-469.

Hausman, J. K. and J. F. Wieland (2014). Abenomics: Preliminary analysis and outlook. Brookings Papers on Economic Activity, 1-63.

Hurd, M. D. and S. Rohwedder (2012). Measuring total household spending in a monthly internet survey: Evidence from the American Life Panel. Technical report, National Bureau of Economic Research.

Ichiue, H. and S. Nishiguchi (2015). Inflation expectations and consumer spending at the zero bound: Micro evidence. Economic Inquiry 53(2), 1086-1107.

Jalil, A. and G. Rua (2015). Inflation expectations and recovery from the depression in 1933: Evidence from the narrative record. Unpublished Manuscript, Federal Reserve Board.

Jonung, L. (1981). Perceived and expected rates of inflation in Sweden. The American Economic Review 71(5), 961-968.

Krugman, P. R. (1998). It's baaack: Japan's slump and the return of the liquidity trap. Brookings Papers on Economic Activity 1998(2), 137-205.

Kuchler, T. and B. Zafar (2015). Personal experiences and expectations about aggregate outcomes. Federal Reserve Bank of New York Staff Reports (748).

Malmendier, U. and S. Nagel (2009). Learning from inflation experiences. Unpublished manuscript, UC Berkeley.

McKay, A., E. Nakamura, and J. Steinsson (2015). The power of forward guidance revisited. Technical report, National Bureau of Economic Research.

Mian, A. and A. Sufi (2012). The effects of fiscal stimulus: Evidence from the 2009 cash for clunkers program. The Quarterly Journal of Economics 127(3), 1107-1142.

Piazzesi, M. and M. Schneider (2009). Momentum traders in the housing market: Survey evidence and a search model. The American Economic Review 99(2), 406-411.

Ramey, V. A. (2011a). Can government purchases stimulate the economy? Journal of Economic Literature 49(3), 673-685.

Ramey, V. A. (2011b). Identifying government spending shocks: It's all in the timing. The Quarterly Journal of Economics 126(1), 1-50.

Ramey, V. A. (2015). Macroeconomic shocks and their propagation. Handbook of 
Macroeconomics, forthcoming.

Romer, C. D. and D. H. Romer (2010). The macroeconomic effects of tax changes: estimates based on a new measure of fiscal shocks. The American Economic Review $100(3), 763-801$.

Romer, C. D. and D. H. Romer (2013). The missing transmission mechanism in the monetary explanation of the Great Depression. The American Economic Review 103(3), 66-72.

SPD (2005). Vertrauen in Deutschland. Das Wahlmanifest der SPD. Electoral Manifest.

Werning, I. (2012). Managing a liquidity trap: monetary and fiscal policy. Unpublished Manuscript, MIT.

Woodford, M. (2011). Simple analytics of the government expenditure multiplier. American Economic Journal: Macroeconomics 3(1), 1-35. 
Figure 2: Expected Increase in Inflation and Average Readiness to Spend on Durables

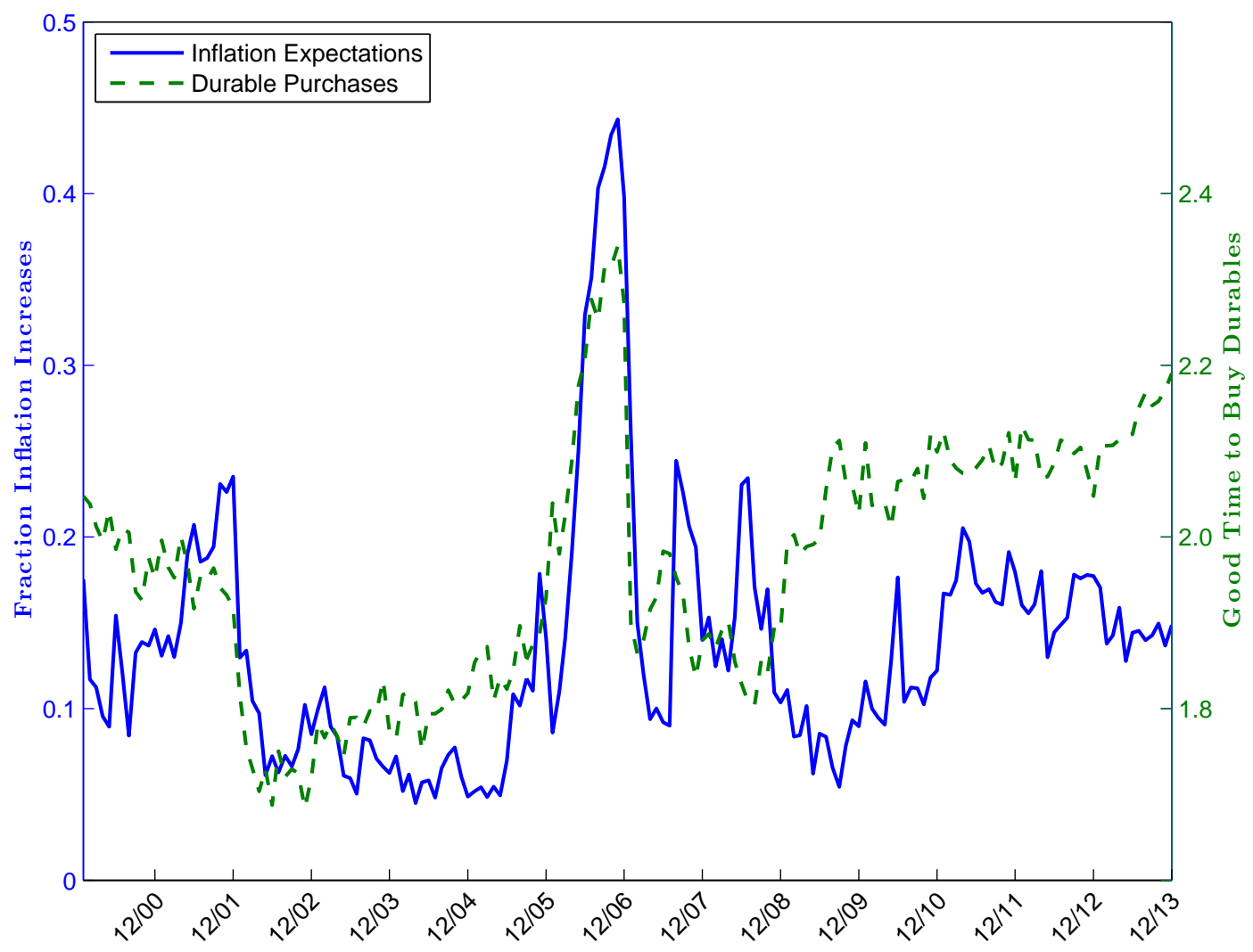

This figure plots average monthly inflation expectation (blue line, left y-axis) and the average monthly readiness to purchase durables (green dashed line, right y-axis) over time. We use the confidential micro data underlying the GfK Consumer Climate MAXX survey to construct these variables. GfK asks a representative sample of 2,000 households how consumer prices will evolve in the next twelve months compared to the previous twelve months and whether it is a good time to purchase durables given the current economic conditions. We create a dummy variable which equals 1 when a household expects inflation to increase. Higher values correspond to better times to purchase durables. The sample period is January 2000 to December 2013 for a total of fourteen years. 
Figure 3: Standardized Lagged Inflation Expectations and Durable Inflation Rate

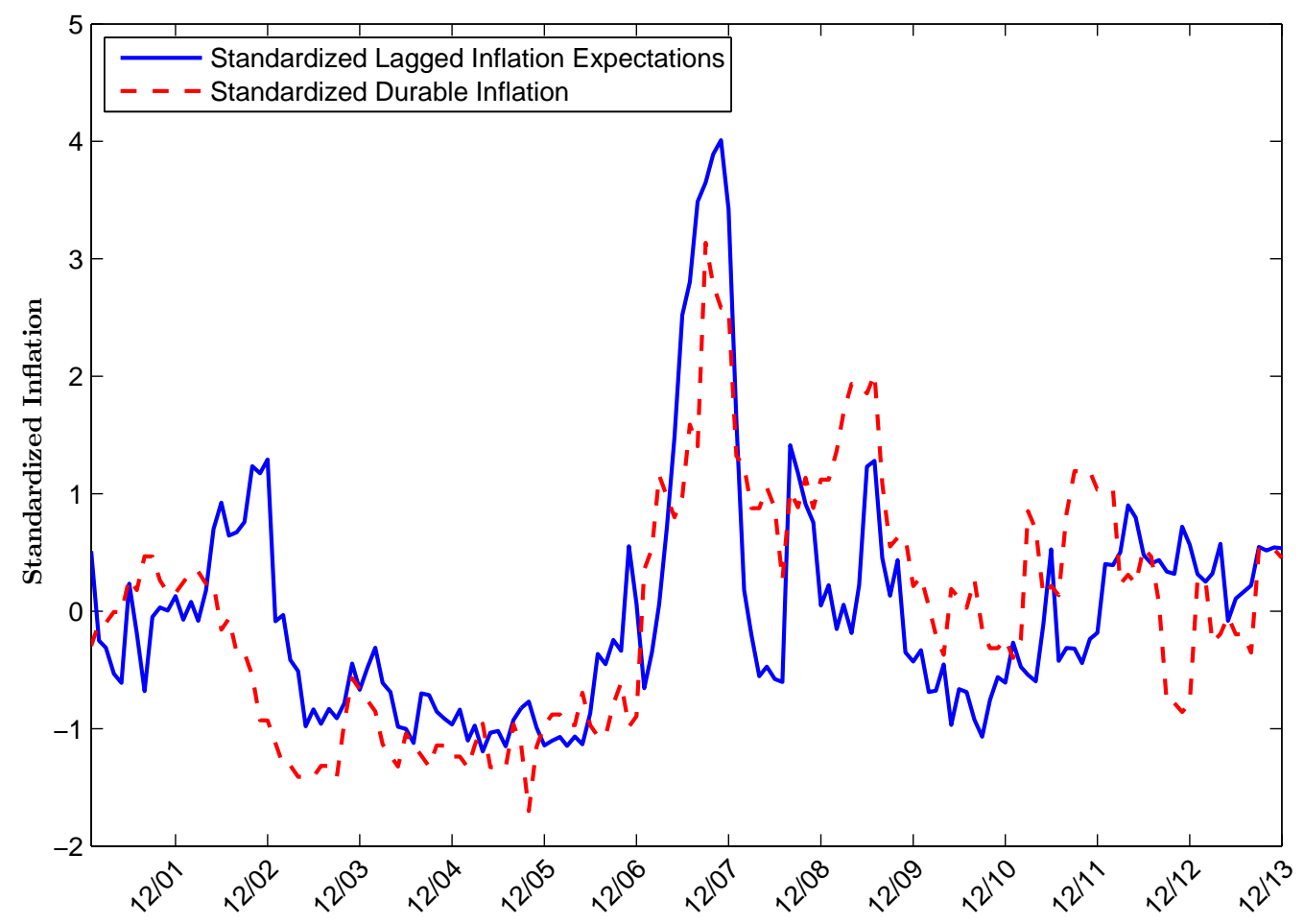

This figure plots the monthly time series of the one-year lagged standardized average monthly inflation expectation and the harmonized major durables consumer price inflation rate in percent at an annual rate. We use the confidential micro data underlying the GfK Consumer Climate MAXX survey to construct inflation expectations. GfK asks a representative sample of 2,000 households how consumer prices will evolve in the next twelve months compared to the previous twelve months. We create a dummy variable which equals 1 when a household expects inflation to increase. The sample period is January 2000 to December 2013 for a total of fourteen years. 


\section{Figure 4: Expected Increase in Inflation: Germany and European Union}

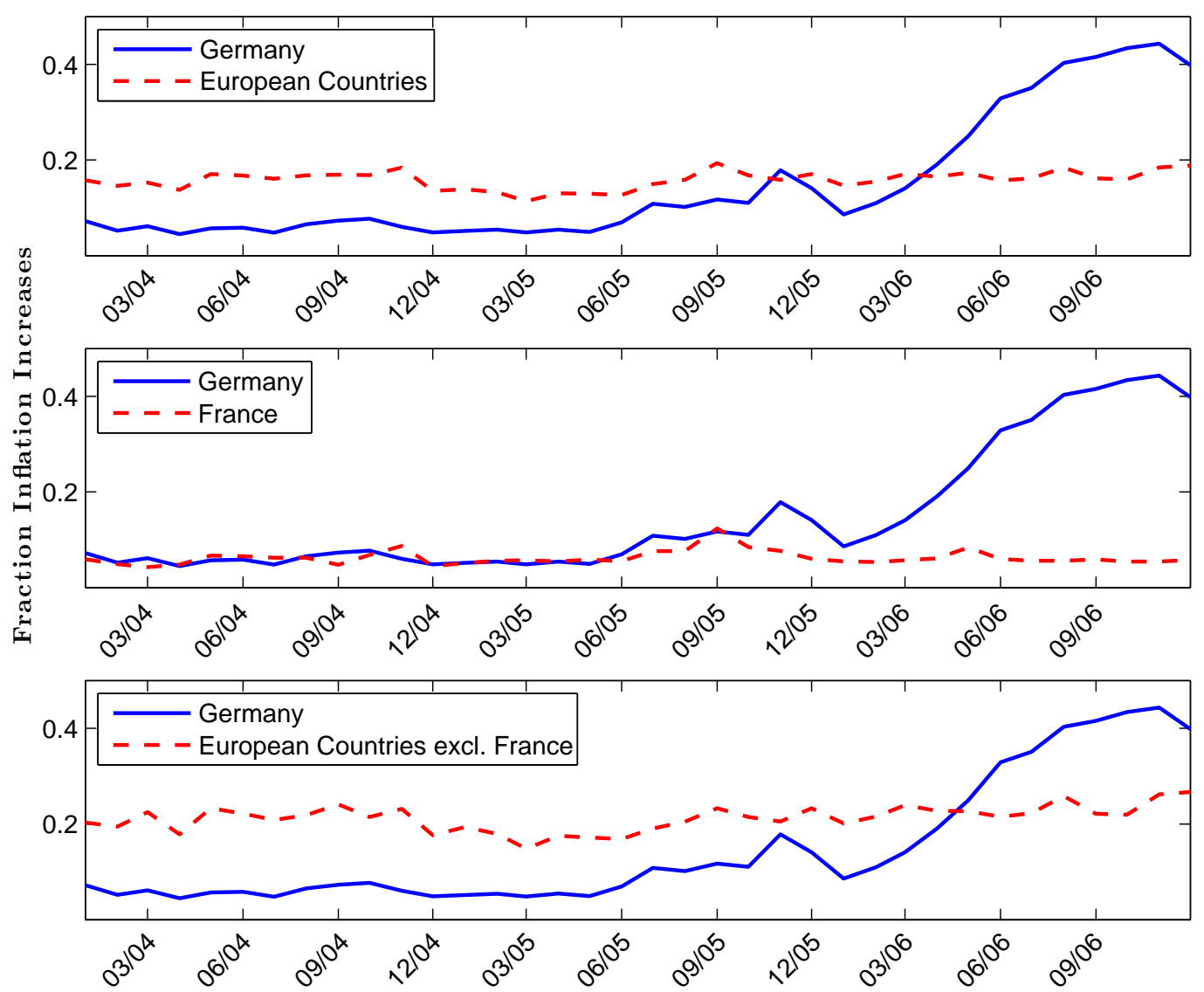

This figure plots average monthly inflation expectation over time. We use the confidential micro data underlying the GfK Consumer Climate MAXX survey to construct the variables for Germany and similar data from national statistical agencies and GfK subsidiaries for the United Kingdom, Sweden, and France. GfK asks a representative sample of 2,000 households how consumer prices will evolve in the next twelve months compared to the previous twelve months. We create a dummy variable which equals 1 when a household expects inflation to increase. The sample period is January 2004 to December 2006 for a total of three years. 


\section{Figure 5: Readiness to Spend on Durables: Germany and European Union}

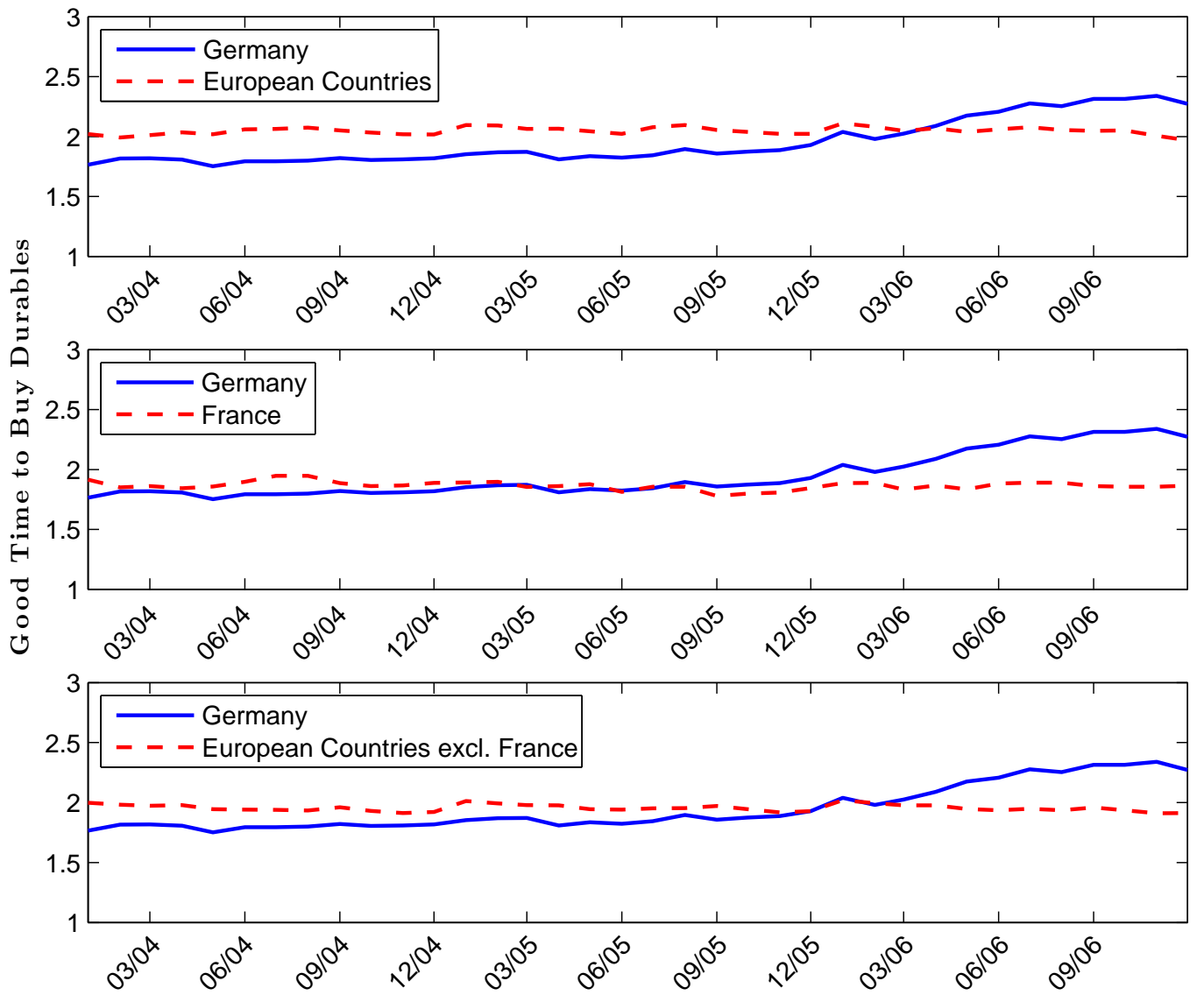

This figure plots the average monthly readiness to purchase durables over time. We use the confidential micro data underlying the GfK Consumer Climate MAXX survey to construct these variables for Germany and similar data from national statistical agencies and GfK subsidiaries for the United Kingdom, Sweden, and France. GfK asks a representative sample of 2,000 households whether it is a good time to purchase durables given the current economic conditions. Higher values correspond to better times to purchase durables. The sample period is January 2004 to December 2006 for a total of three years. 
Figure 6: Common Support of Treated and Matched Households

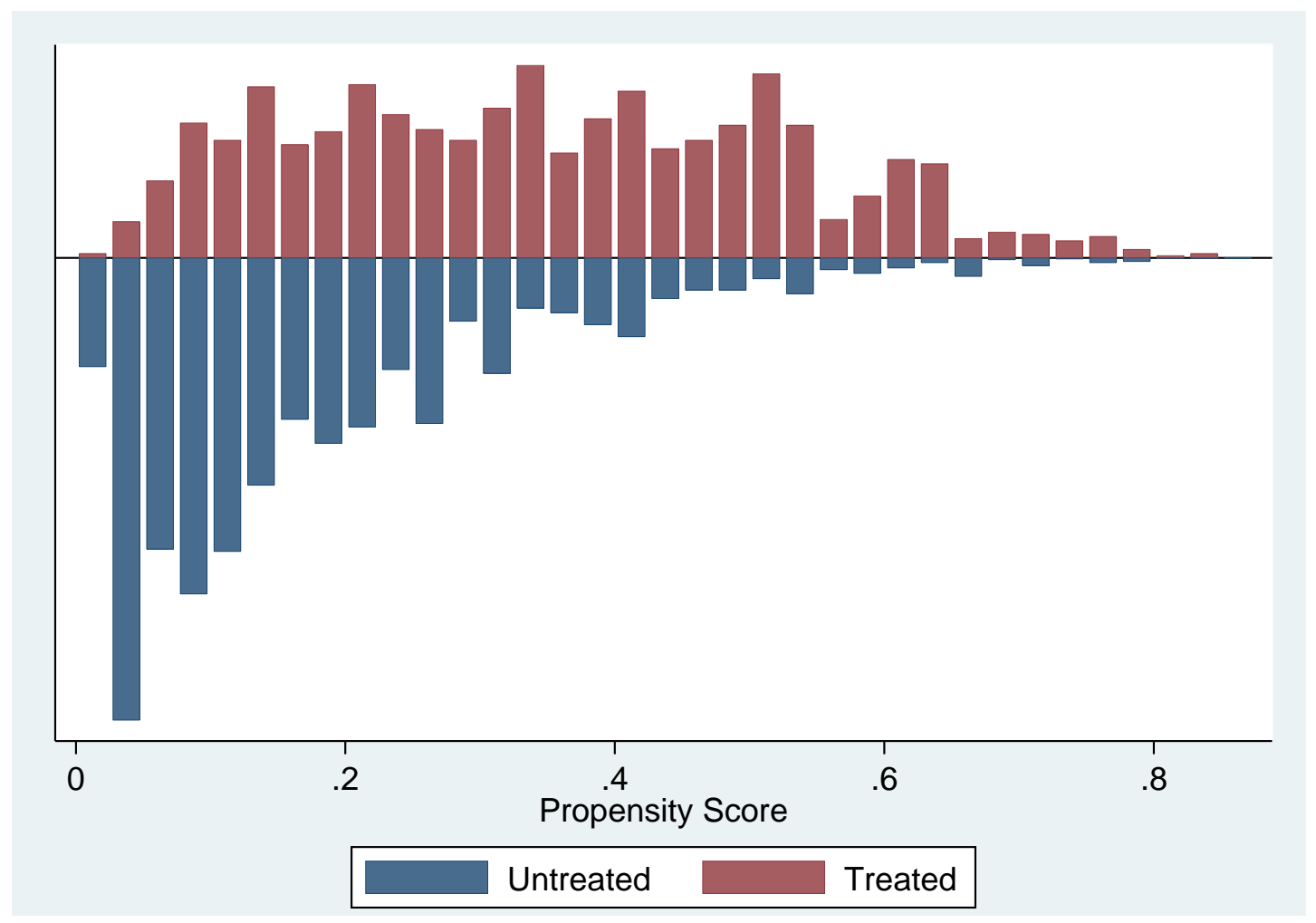

This figure plots the number of households in the untreated (blue) and treated (red) group across forty equal-length partitions of the distribution of the propensity score in the baseline month (June 2005) for the difference-in-differences analysis. We estimate the propensity score with a logit specification whose outcome variable is the indicator for whether a household is in the treated or control group, and the controls are the observables we use for the matching of households: age group, gender, education group, income group, and social status group. The treated group includes 1,431 German households, whereas the control group includes 5,108 households from the UK, France, and Sweden. 
Figure 7: Household Expectations

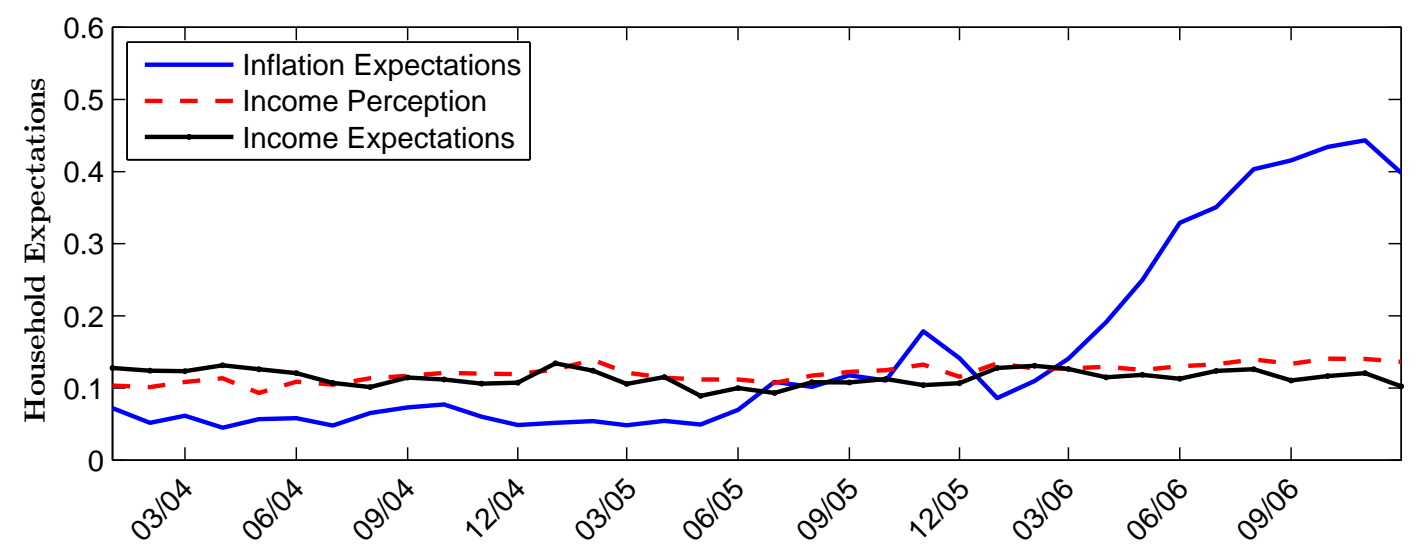

This figure plots average monthly inflation expectation, perception of past income, and expectation of future income over time. We use the confidential micro data underlying the GfK Consumer Climate MAXX survey to construct those variables. GfK asks a representative sample of 2,000 households how consumer prices will evolve in the next twelve months compared to the previous twelve months, how the financial situation of the household evolved during the past twelve months, and how the financial situation of the household will evolve during the next twelve months. We create a dummy variable which equals 1 when a household expects inflation to increase, perceives an improved financial situation, and expects an improved financial situation. The sample period is January 2004 to December 2006 for a total of three years. 
Figure 8: Real Aggregate Consumption Growth

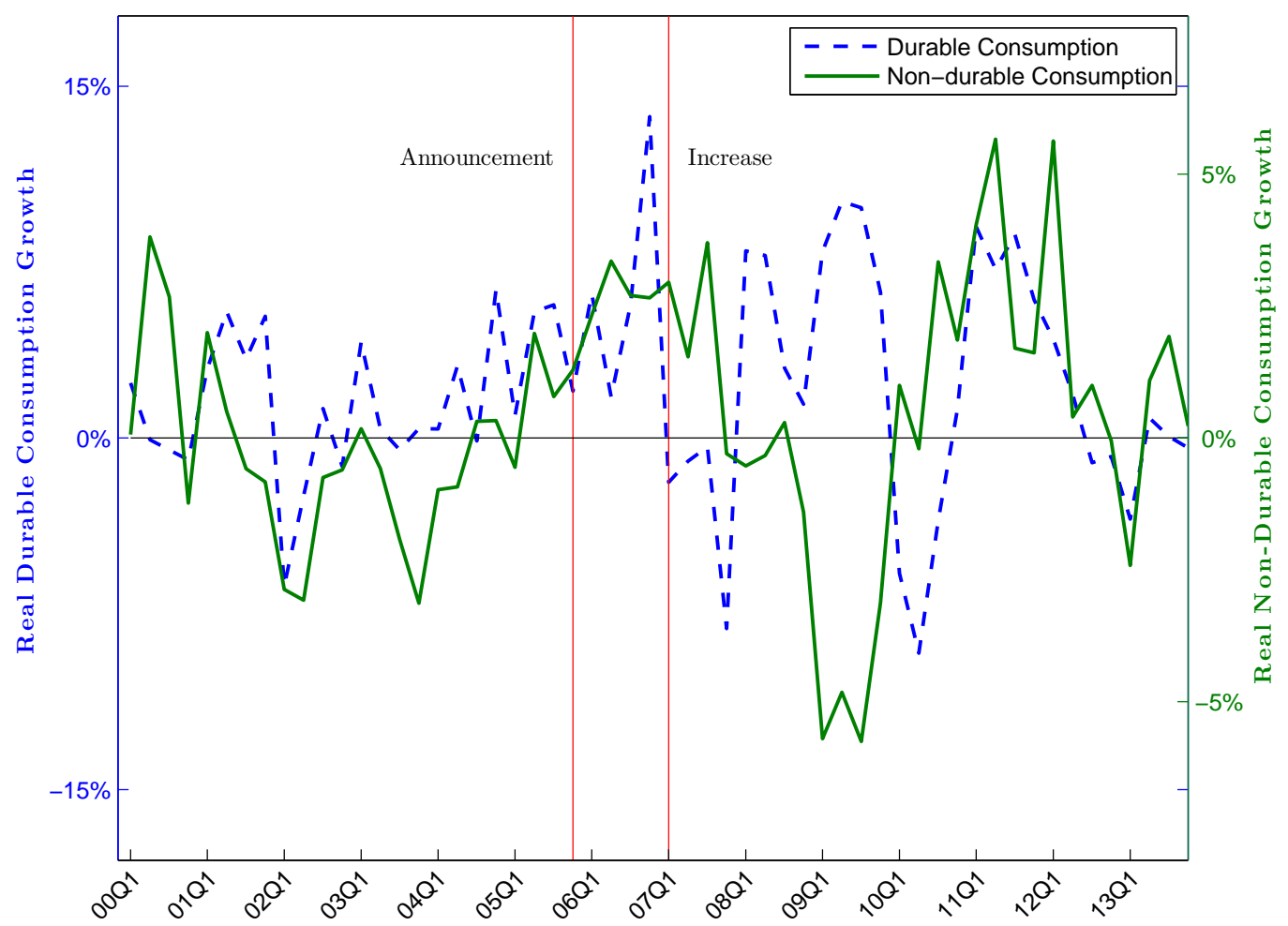

This figure plots real durable (blue dashed line, left y-axis) and non-durable (green line, right y-axis) consumption growth at the quarterly frequency from the German statistical office Destatis. The sample period is the first quarter of 2000 to the fourth quarter of December 2013 for a total of fourteen years. 
Figure 9: Change in the Readiness to Spend on Durables for German vs. Foreign Households

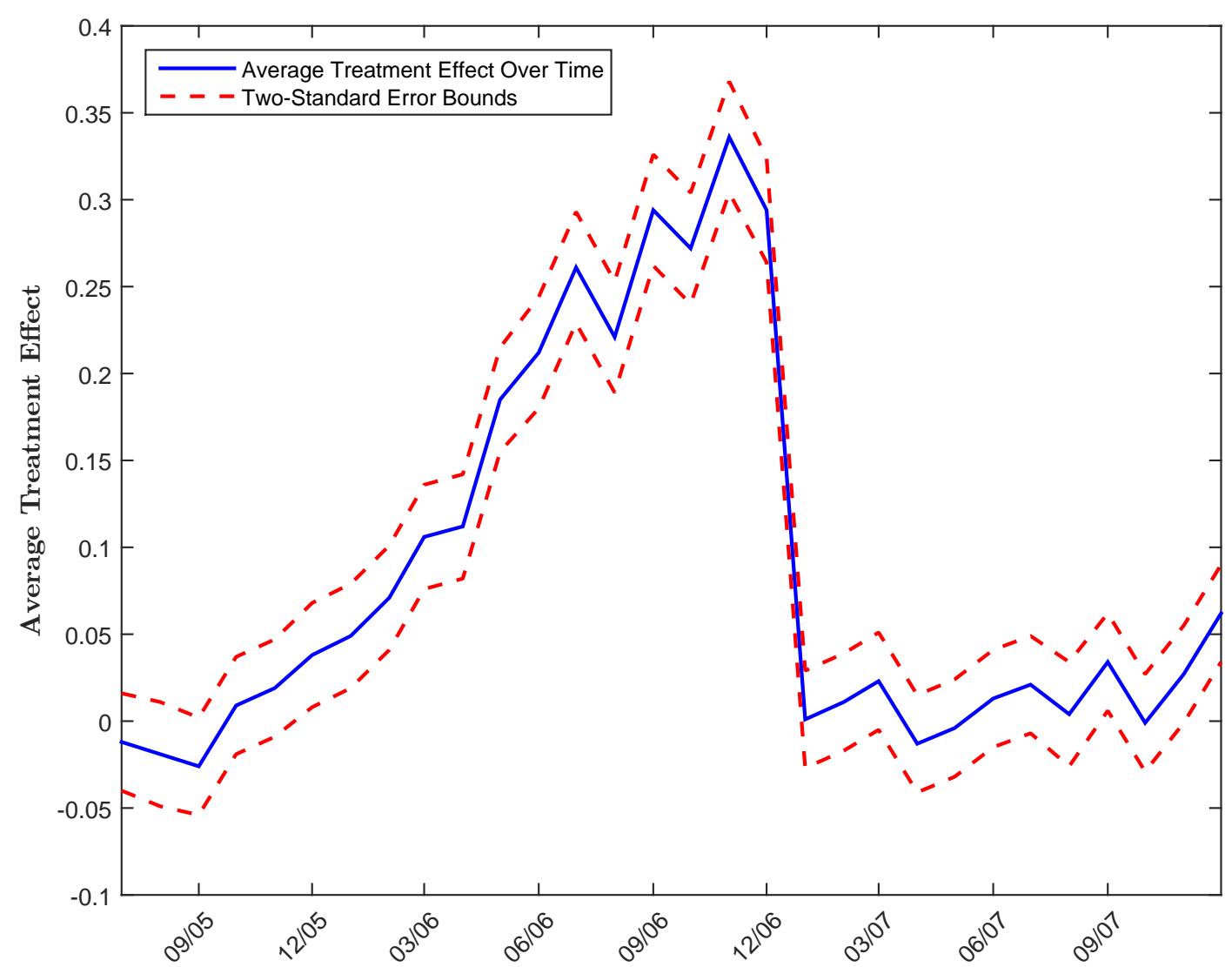

This figure plots $\beta_{m}$ coefficient (solid line) of $\Delta$ Dur $_{i, 06 / 2005 \rightarrow m}=\alpha+\beta_{m} \times V$ ATshock $k_{i}+\Delta X_{i, 06 / 2005 \rightarrow m}^{\prime} \times \gamma+$ $\epsilon_{i}$ and two standard deviation error bands (dashed line). $\Delta D$ ur $_{i, 06 / 2005 \rightarrow m}$ is the difference in the willingness to spend on durable goods between month $m$ and June 2005, VATshock $k_{i}$ is an indicator which equals 1 if the household was exposed to the VAT shock, $\beta_{m}$ captures the effect of the VAT shock on the willingness to buy durables for household $i$ in month $m$, and $\Delta X_{i, 06 / 2005 \rightarrow m}^{\prime}$ is the difference in a set of observables between month $m$ and the baseline month. We use the micro data underlying the Directorate-General for Economic and Financial Affairs of the European Commission harmonized consumer surveys to construct these variables. 


\section{Figure 10: Cyclical Readiness to Spend on Durables and Real Durable Consumption}

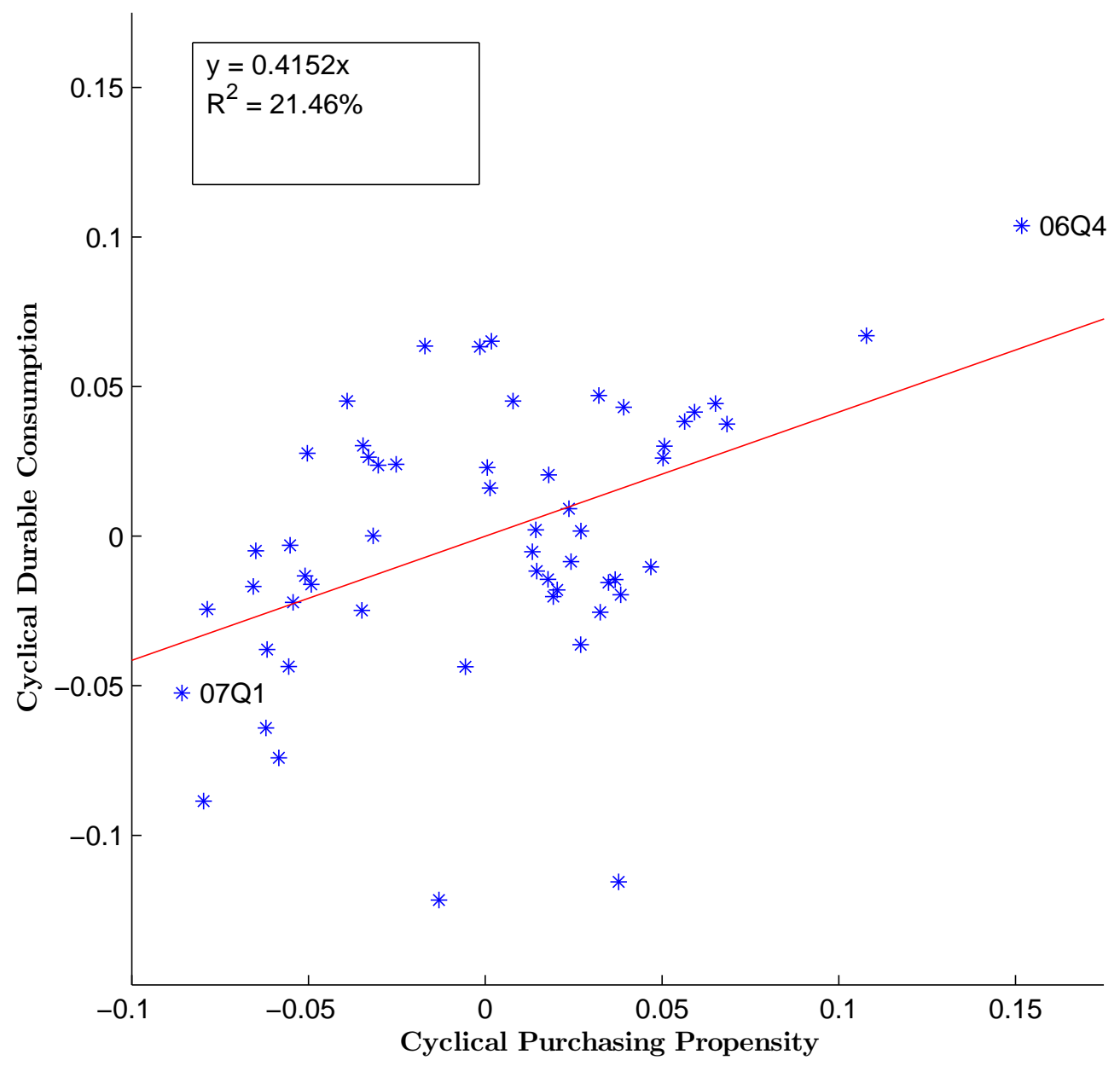

This figure is a scatter plot of the cyclical components of the average monthly readiness to purchase durables over time and of the natural logarithm of the real durable consumption at the quarterly frequency. We use a Hodrick-Prescott filter with smoothing parameter $\lambda=1,600$ to estimate the cyclical component. We use the confidential micro data underlying the GfK Consumer Climate MAXX survey to construct the readiness to purchase durables index. GfK asks a representative sample of 2,000 households whether it is a good time to purchase durables given the current economic conditions. Higher values correspond to better times. We use the end of quarter value to get a quarterly time series. The sample period is fist quarter 2000 to fourth quarter 2013 for a total of fourteen years. 


\section{Table 1: Descriptive Statistics}

This table reports descriptive statistics for households' inflation expectations and readiness to purchase durables in Panel A, household demographics in Panel B, household expectations and perceptions in Panel C, and macroeconomics aggregates in Panel D. We use the confidential micro data underlying the GfK Consumer Climate MAXX survey to measure the variables in Panel A to Panel C. GfK asks a representative sample of 2,000 households questions about general economic expectations, income expectations, and willingness to buy in order to create an aggregate measure labeled "consumer climate." For Panel A, GfK asks whether it is a good time to purchase durables given the current economic conditions. GfK also asks how consumer prices will evolve in the next twelve months compared to the previous twelve months. Inflation increase is a dummy variable which equals 1 when a household replies that inflation will increase. GfK also asks how consumer prices evolved in the previous twelve months. See the online appendix for data sources and detailed data definitions. The sample period is January 2000 to December 2013 for a total of fourteen years.

\begin{tabular}{|c|c|c|c|c|c|c|c|c|c|}
\hline & & Nobs & Mean & Std & Min & $\mathrm{p} 25$ & $\mathrm{p} 50$ & $\mathrm{p} 75$ & Max \\
\hline \multicolumn{10}{|c|}{ Panel A: Inflation expectations and readiness to spend } \\
\hline \multirow[t]{3}{*}{ Readiness to buy durables } & Good time & 326,011 & $20.26 \%$ & & & & & & \\
\hline & Neither & & $56.15 \%$ & & & & & & \\
\hline & Bad time & & $23.59 \%$ & & & & & & \\
\hline \multirow{6}{*}{$\begin{array}{l}\text { Inflation increase } \\
\text { Inflation perception }\end{array}$} & & 355,400 & $13.77 \%$ & 0.34 & 0 & 0 & 0 & 0 & 1 \\
\hline & increased substantially & 348,521 & $28.06 \%$ & & & & & & \\
\hline & increased somewhat & & $29.69 \%$ & & & & & & \\
\hline & increased slightly & & $27.80 \%$ & & & & & & \\
\hline & remained the same & & $13.23 \%$ & & & & & & \\
\hline & decreased & & $1.23 \%$ & & & & & & \\
\hline \multicolumn{10}{|c|}{ Panel B: Household demographics } \\
\hline \multirow{2}{*}{ Sex } & Male & 355,400 & $53.83 \%$ & & & & & & \\
\hline & Female & & $46.17 \%$ & & & & & & \\
\hline \multicolumn{2}{|l|}{ Age } & 355,400 & 46.07 & 17.49 & 14 & 33 & 45 & 60 & 99 \\
\hline \multirow[t]{4}{*}{ Education } & Hauptschule & 350,093 & $42.74 \%$ & & & & & & \\
\hline & Realschule & & $38.96 \%$ & & & & & & \\
\hline & Gymnasium & & $10.34 \%$ & & & & & & \\
\hline & Universitaet & & $7.97 \%$ & & & & & & \\
\hline \multicolumn{2}{|l|}{ Household members } & 355,400 & 2.49 & 1.17 & 1 & 2 & 2 & 3 & 5 \\
\hline \multirow[t]{4}{*}{ City } & City $<9,999$ & 355,400 & $28.24 \%$ & & & & & & \\
\hline & $9,999<=$ City $<49,999$ & & $34.46 \%$ & & & & & & \\
\hline & $50,000<=$ City $<199,999$ & & $15.66 \%$ & & & & & & \\
\hline & $199,999<=$ City & & $21.64 \%$ & & & & & & \\
\hline \multirow[t]{2}{*}{ Kids at home } & yes & 355,400 & $26.88 \%$ & & & & & & \\
\hline & no & & $73.12 \%$ & & & & & & \\
\hline \multirow{5}{*}{$\begin{array}{l}\text { Number of kids } \\
\text { Net income (inc) }\end{array}$} & & 352,256 & 0.42 & 0.78 & 0 & 0 & 0 & 1 & 4 \\
\hline & inc $<1,000$ & 270,592 & $43.60 \%$ & & & & & & \\
\hline & $1,000<=$ inc $<1,500$ & & $28.66 \%$ & & & & & & \\
\hline & $1,500<=$ inc $<2,500$ & & $20.81 \%$ & & & & & & \\
\hline & $2,500<=$ inc & & $6.93 \%$ & & & & & & \\
\hline \multicolumn{10}{|c|}{ Panel C: Household expectations and perceptions } \\
\hline \multirow[t]{5}{*}{ Past Financial situation } & Improved substantially & 351,486 & 0.02 & & & & & & \\
\hline & Improved somewhat & & 0.12 & & & & & & \\
\hline & Identical & & 0.61 & & & & & & \\
\hline & Worsened somewhat & & 0.21 & & & & & & \\
\hline & Worsened substantially & & 0.05 & & & & & & \\
\hline \multirow[t]{5}{*}{ Financial outlook } & Improves substantially & 341,105 & 0.01 & & & & & & \\
\hline & Improves somewhat & & 0.11 & & & & & & \\
\hline & Identical & & 0.73 & & & & & & \\
\hline & Worsens somewhat & & 0.13 & & & & & & \\
\hline & Worsens substantially & & 0.02 & & & & & & \\
\hline \multirow[t]{5}{*}{ Current financial situation } & Save a lot & 345,683 & 0.04 & & & & & & \\
\hline & Save little & & 0.39 & & & & & & \\
\hline & Don't save & & 0.41 & & & & & & \\
\hline & Dissave & & 0.13 & & & & & & \\
\hline & Take on debt & & 0.02 & & & & & & \\
\hline \multirow[t]{5}{*}{ Expected unemployment rate } & Increases substantially & 342,563 & 14.10 & & & & & & \\
\hline & Increases somewhat & & 32.24 & & & & & & \\
\hline & Identical & & 35.28 & & & & & & \\
\hline & Decreases somewhat & 38 & 17.27 & & & & & & \\
\hline & Decreases a lot & & 1.12 & & & & & & \\
\hline
\end{tabular}


Table 1: Descriptive Statistics continued

Continued from previous page.

\begin{tabular}{lcccccccc}
\hline & Nobs & Mean & Std & Min & p25 & p50 & p75 & Max \\
\hline Panel D: Macroeconomic aggregates & & & & & & & \\
\hline CPI Inflation & 355,400 & $1.61 \%$ & $0.65 \%$ & $-0.50 \%$ & $1.21 \%$ & $1.64 \%$ & $1.98 \%$ & $3.27 \%$ \\
Unemployment rate & 355,400 & 8.99 & 1.61 & 6.40 & 7.60 & 9.00 & 10.30 & 12.70 \\
European Uncertainty Index & 355,400 & 134.25 & 62.78 & 46.61 & 83.54 & 116.53 & 170.93 & 331.54 \\
German Uncertainty Index & 355,400 & 119.79 & 57.60 & 28.43 & 79.13 & 106.68 & 144.33 & 377.84 \\
MRO rate & 355,400 & 3.09 & 1.53 & 0.25 & 1.00 & 4.25 & 4.25 & 4.25 \\
Dax & 355,400 & 5840 & 1511 & 2424 & 4769 & 5970 & 6949 & 9552 \\
Volatility DAX & 355,400 & 22.79 & 8.67 & 11.24 & 16.88 & 20.62 & 25.91 & 57.96 \\
Industrial Production Growth & 355,400 & $1.60 \%$ & $6.97 \%$ & $-27.25 \%$ & $0.00 \%$ & $2.41 \%$ & $5.65 \%$ & $14.55 \%$ \\
Oil Price & 355,400 & 63.42 & 33.66 & 18.71 & 29.80 & 58.76 & 94.99 & 132.72 \\
\hline
\end{tabular}




\section{Table 2: Inflation Expectations and Readiness to Spend: Baseline}

This table reports the average marginal effects of a multinomial logit regression. Households' readiness to purchase durables is the dependent variable. Inflation increase is a dummy variable which equals 1 when a household replies that inflation will increase. Past inflation measures the household perception of the increase in consumer prices during the last twelve months. We also control for household demographics, household expectations, and contemporaneous macroeconomic variables where indicated. We use the confidential micro data underlying the GfK Consumer Climate MAXX survey to construct these variables. GfK asks a representative sample of 2,000 households on a monthly basis whether it is a good time to purchase durables given the current economic conditions. Households can reply that it is a good time, it is a bad time, or it is neither a good time nor a bad time. Standard errors are clustered at the quarter level (56 clusters). The sample period is January 2000 to December 2013.

\begin{tabular}{lccccc}
\hline & $(1)$ & $(2)$ & $(3)$ & $(4)$ & $(5)$ \\
\hline Inflation expectation & $0.0624^{* * *}$ & $0.0749^{* * *}$ & $0.0755^{* * *}$ & $0.0888^{* * *}$ & $0.0875^{* * *}$ \\
& $(0.0162)$ & $(0.0152)$ & $(0.0156)$ & $(0.0160)$ & $(0.0116)$ \\
Past Inflation & & $-0.0342^{* * *}$ & $-0.0300^{* * *}$ & $-0.0200^{* * *}$ & $-0.0114^{* * *}$ \\
& & $(0.0028)$ & $(0.0030)$ & $(0.0035)$ & $(0.0023)$ \\
& & & & $\mathrm{X}$ & $\mathrm{X}$ \\
Demographics & & $\mathrm{X}$ & $\mathrm{X}$ & $\mathrm{X}$ \\
Individual expectations & & & & $\mathrm{X}$ \\
Macro aggregates & & & 0.0292 & 0.0654 & 0.0762 \\
Pseudo R & & & & 219,799 & 219,799 \\
Nobs & 0.0031 & 321,496 & 244,497 & &
\end{tabular}

Standard errors in parentheses

$* p<0.10, * * p<0.05, * * * p<0.01$ 


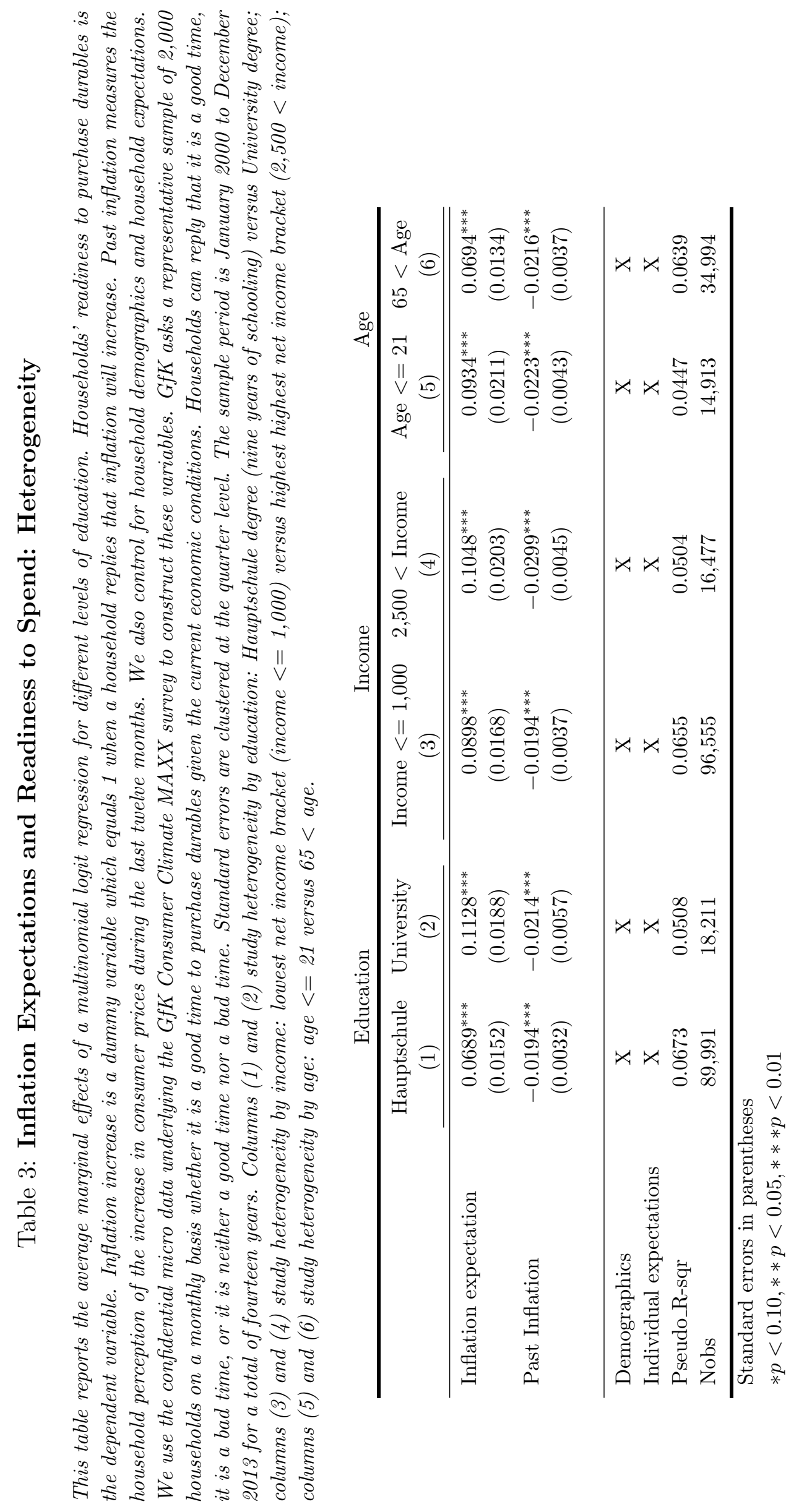




\section{Table 4: Inflation Expectations and Readiness to Spend: matched sample}

This table reports the average marginal effects of a multinomial logit regression. Households' readiness to purchase durables is the dependent variable. Inflation increase is a dummy variable which equals 1 when a household replies that inflation will increase. Past inflation measures the household perception of the increase in consumer prices during the last twelve months. We use the confidential micro data underlying the Directorate-General for Economic and Financial Affairs of the European Commission harmonized consumer surveys to construct these variables. The surveys ask representative samples of households on a monthly basis whether it is a good time to purchase durables given the current economic conditions. Households can reply that it is a good time, it is a bad time, or it is neither a good time nor a bad time. In this table we study the "it is a good time" outcome. Standard errors are clustered at the quarter level. The sample period is January 2004 to December 2012 for France, Sweden, and the United Kingdom. The sample period is January 2004 to October 2005 and January 2007 to December 2012. We use the longest sample for which we have data on all countries.

\begin{tabular}{lcccc}
\hline & & & & Germany excl \\
& France & Sweden & UK & VAT period \\
& $(1)$ & $(2)$ & $(3)$ & $(4)$ \\
\hline Inflation expectation & $0.0265^{* * *}$ & $0.0265^{* * *}$ & $0.0402^{* * *}$ & $0.0555^{* * *}$ \\
& $(0.0037)$ & $(0.0049)$ & $(0.0067)$ & $(0.0037)$ \\
Past Inflation & $-0.0163^{* * *}$ & $-0.0438^{* * *}$ & $-0.0294^{* * *}$ & $-0.0140^{* * *}$ \\
& $(0.0015)$ & $(0.0051)$ & $(0.0019)$ & $(0.0039)$ \\
& & & & $\mathrm{X}$ \\
Demographics & $\mathrm{X}$ & $\mathrm{X}$ & $\mathrm{X}$ & $\mathrm{X}$ \\
Individual expectations & $\mathrm{X}$ & $\mathrm{X}$ & $\mathrm{X}$ & 0.0641 \\
Pseudo R & 0.0445 & 0.0317 & 0.0446 & 125,407 \\
Nobs & 163,419 & 141,903 & 87,864 & \\
\hline Standard & & & &
\end{tabular}

Standard errors in parentheses

$* p<0.10, * * p<0.05, * * * p<0.01$ 


\section{Table 5: Balancing of Variables - German and Foreign Households (June 2005)}

This table describes the balancing of the observables we use to match treated and control households in the baseline month (June 2005) for the difference-in-differences analysis. For each variable, the first column reports the mean within the pool of control households (UK, France, and Sweden). The second column reports the mean within the pool of treated German households. The third and fourth column report the results for a two-sided t-test whose null hypothesis is that the means across groups are equal. The two pools are constituted by 1,431 households (treated) and 5,108 households (control) that overlap on the same common support.

\begin{tabular}{lcccc}
\hline Variable & Mean Control & Mean Treated & t-stat & p-value \\
\hline Age (four groups) & 2.33 & 2.30 & 1.01 & 0.31 \\
Male & 0.47 & 0.47 & 0.22 & 0.82 \\
Education (three groups) & 1.77 & 1.81 & -1.15 & 0.25 \\
Income (four quartiles) & 2.31 & 2.28 & 0.8 & 0.42 \\
Social Status (three groups) & 2.60 & 2.61 & -0.37 & 0.71 \\
& & & & \\
\hline Obs in common support & 5,108 & 1,431 & & \\
\hline
\end{tabular}




\title{
Online Appendix: Inflation Expectations and Consumption Expenditure
}

\author{
Francesco D'Acunto, Daniel Hoang, and Michael Weber
}

Not for Publication

\section{Survey Questions}

Below we report the original survey questions with answer choices for Germany, the English translation, and the harmonized surveys from the Directorate-General for Economic and Financial Affairs of the European Commission harmonized consumer surveys used in Section IV for the matching estimator.

\section{A. Germany}

Question 1 Wie hat sich Ihrer Meinung nach die "allgemeine Wirtschaftslage" in Deutschland in den letzten 12 Monaten entwickelt?

Sie ...

- hat sich wesentlich verbessert

- hat sich etwas verbessert

- ist in etwa gleich geblieben

- hat sich etwas verschlechtert

- hat sich wesentlich verschlechtert

- weiss nicht

Question 2 Wie haben sich Ihrer Ansicht nach die Verbraucherpreise in den letzten 12 Monaten entwickelt?

Sie sind $\ldots$

- stark gestiegen

- in Massen gestiegen

- leicht gestiegen

- in etwa gleich geblieben

- gesunken

- weiss nicht

Question 3 Wie werden sich Ihrer Ansicht nach die Verbraucherpreise in den kommenden 12 Monaten im Vergleich zu den letzten 12 Monaten entwickeln?

Sie werden ... 
- staerker als bisher steigen

- etwa im gleichen Masse wie bisher steigen

- weniger stark als bisher steigen

- in etwa gleich bleiben

- gesunken

- weiss nicht

Question 4 Wie hat sich die finanzielle Lage Ihres Haushaltes in den letzten 12 Monaten entwickelt?

Sie ...

- hat sich wesentlich verbessert

- hat sich etwas verbessert

- ist in etwa gleichgeblieben

- hat sich etwas verschlechtert

- hat sich wesentlich verschlechtert

- weiss nicht

Question 5 Wie wird sich Ihrer Ansicht nach die finanzielle Lage Ihres Haushaltes in den kommenden 12 Monaten entwickeln?

Sie wird ...

- sich wesentlich verbessern

- sich etwas verbessern

- in etwa gleichbleiben

- sich etwas verschlechtern

- sich wesentlich verschlechtern

- weiss nicht

Question 6 Wie wird sich Ihrer Ansicht nach die allgemeine Wirtschaftslage in Deutschland in den kommenden 12 Monaten entwickeln?

Sie wird ...

- sich wesentlich verbessern

- sich etwas verbessern

- in etwa gleichbleiben

- sich etwas verschlechtern

- sich wesentlich verschlechtern

- weiss nicht

Question 7 Wie ist die derzeitige finanzielle Lage Ihres Haushaltes?

- wir sparen viel

- wir sparen ein wenig

- wir kommen mit unseren finanziellen Mitteln so gerade aus

- wir greifen etwas unsere Ersparnisse an

- wir verschulden uns 
- weiss nicht

Question 8 Glauben Sie, dass es in Anbetracht der allgemeinen Wirtschaftslage derzeit guenstig ist, groessere Anschaffungen (Moebel, elektrische/elektronische Geraete usw.) zu taetigen?

- ja, jetzt der Augenblick ist guenstig

- der Augenblick ist weder besonders guenstig noch besonders unguenstig

- nein, der Augenblick ist nicht guenstig

- weiss nicht

Question 10 Wie wird sich Ihrer Ansicht nach die Zahl der Arbeitslosen in Deutschland in den kommenden 12 Monaten entwickeln?

Die Zahl wird ...

- stark steigen

- leicht steigen

- in etwa gleich bleiben

- leicht zurueckgehen

- stark zurueckgehen

- weiss nicht

Question 11 Wollen Sie in den kommenden 12 Monaten fuer groessere Anschaffungen (Moebel, elektrische /elektronische Geraete usw.) mehr oder weniger ausgeben als in den letzten 12 Monaten?

Ich werde ...

- wesentlich mehr ausgeben

- etwas mehr ausgeben

- in etwa gleich viel ausgeben

- etwas weniger ausgeben

- wesentlich weniger ausgeben

- weiss nicht

Question 12 Wie wahrscheinlich ist es, dass Sie in den kommenden 12 Monaten Geld sparen werden?

- sehr wahrscheinlich

- recht wahrscheinlich

- unwahrscheinlich

- sehr unwahrscheinlich

- weiss nicht

Question 13 Glauben Sie, dass es in Anbetracht der allgemeinen Wirtschaftslage derzeit ratsam ist, zu sparen?

- ja, auf alle Faelle

- wahrscheinlich ja 
- eher nicht

- auf keinen Fall

- weiss nicht

Question 1 How did you perceive the general economic situation in Germany over the last 12 months?

It ...

- improved substantially

- improved somewhat

- remained about the same

- worsened somewhat

- worsened substantially

- don't know

Question 2 What is your perception on how consumer prices evolved during the last 12 months?

They ...

- increased substantially

- increased somewhat

- increased slightly

- remained about the same

- decreased

- don't know

Question 3 How will consumer prices evolve during the next 12 months compared to the previous 12 months?

They will ...

- increase more

- increase the same

- increase less

- stay the same

- decrease

- don't know

Question 4 How did the financial situation of your household evolve during the past 12 months?

It ...

- improved substantially

- improved somewhat

- remained about the same

- worsened somewhat

- worsened substantially 
- don’t know

Question 5 How will the financial situation of your household evolve during the next 12 months?

It will ...

- improve substantially

- improve somewhat

- remain the same

- worsen slightly

- worsen substantially

- don't know

Question 6 How will the general economic situation in Germany evolve during the next 12 months?

It will ...

- improve substantially

- improve slightly

- remain the same

- worsen slightly

- worsen substantially

- don't know

Question 7 What is the current financial situation of your household?

- we save a lot

- we save a bit

- we just manage to live from our financial inflows and don't save

- we have to de-save

- we become indebted

- don't know

Question 8 Given the current economic situation, do you think it's a good time to buy larger items such as furniture, electronic items etc?

- yes, it's a good time

- the time is neither good nor bad

- no, it's a bad time

- don't know

Question 10 What is your expectation regarding the number of unemployed people in Germany in the next 12 months?

It will ...

- increase substantially

- increase somewhat 
- remain the same

- decrease somewhat

- decrease a lot

- don't know

Question 11 Do you plan to spend more money during the next 12 months on larger items such as furniture, electronics, etc compared to the previous 12 months?

I will ...

- spend substantially more

- spend somewhat more

- spend about the same

- spend somewhat less

- spend substantially less

- don't know

Question 12 How likely is it that you will save money during the next 12 months?

- very likely

- quite likely

- unlikely

- very unlikely

- don't know

Question 13 Given the current economic situation, do you think it's a good time to save right now?

- yes, it's a good time

- probably yes

- not really

- not at all

- don't know 


\section{B. France}

Question 1 A votre avis, au cours des douze derniers mois, la situation économique générale de la France...

- s'est nettement améliorée

- s'est un peu améliorée

- est restée stationnaire

- s'est un peu dégradée

- s'est nettement dégradée

- ne sait pas

Question 2 A votre avis, au cours des douze prochains mois, la situation économique générale de la France...

- va nettement s'améliorer

- va un peu s'améliorer

- va rester stationnaire

- va un peu se dégrader

- va nettement se dégrader

- ne sait pas

Question 3 Pensez-vous que, dans les douze prochains mois, le nombre de chômeurs va ...

- fortement augmenter

- un peu augmenter

- rester stationnaire

- un peu diminuer

- fortement diminue

- ne sait pas

Question 4 Trouvez-vous que, au cours des douze derniers mois, les prix ont ...

- fortement augmenté

- moyennement augmenté

- un peu augmenté

- stagné

- diminué

- ne sait pas

Question 5 Par rapport aux douze derniers mois, quelle sera $\tilde{A}$ votre avis l'évolution des prix au cours des douze prochains mois?

- elle va être plus rapide

- elle va se poursuivre au même rythme

- elle va être moins rapide

- les prix vont rester stationnaires

- les prix vont diminuer

- ne sait pas 
Question 6 Dans la situation économique actuelle, pensez-vous que les gens aient intérêt à faire des achats importants? (meubles, machines à laver, matériels électroniques ou informatiques ...)

- oui, le moment est plutôt favorable

- le moment n'est ni favorable ni défavorable ...

- non, le moment est plut $\tilde{A}^{\prime} t$ défavorable

- ne sait pas

Question 7 Dans la situation économique actuelle, pensez-vous que ce soit le bon moment pour épargner?

- oui, certainement

- oui, peut-ètre

- non, probablement pas

- non, certainement pas

- ne sait pas

Question 8 A votre avis, au cours des douze derniers mois, le niveau de vie en France, dans l'ensemble s'est ...

- nettement amélioré

- un peu amélioré

- restée stationnaire

- un peu dégradé

- nettement dégradé

- ne sait pas

Question 9 A votre avis, au cours des douze prochains mois, le niveau de vie en France, dans l'ensemble va ...

- nettement s'améliorer

- s'améliorer un peu

- rester stationnaire

- se dégrader un peu

- nettement se dégrader

- ne sait pas

Question 10 Laquelle des affirmations suivantes vous semble décrire le mieux la situation financière actuelle de votre foyer?

- vous arrivez à mettre pas mal d'argent de còté

- vous arrivez à mettre un peu d'argent de còté

- vous bouclez juste votre budget

- vous tirez un peu sur vos réserves

- vous ètes en train de vous endetter

- ne sait pas

Question 11 Au cours des douze derniers mois, la situation financière de votre foyer s'est ... 
- nettement améliorée

- un peu améliorée

- restée stationnaire

- un peu dégradée

- un peu dégradée

- ne sait pas

Question 12 Pensez-vous que, au cours des douze prochains mois, la situation financière de votre Foyer va ...

- nettement s'améliorer

- un peu s'améliorer

- rester stationnaire

- un peu se dégrader

- nettement se dégrader

- ne sait pas

Question 13 Pensez-vous réussir à mettre de l'argent de côté au cours des douze prochains mois?

- oui, certainement

- oui, peut-être

- non, probablement pas

- non, certainement pas

- ne sait pas

Question 14 Au cours des douze prochains mois, par rapport aux douze mois passés, avez-vous l'intention de dépenser, pour effectuer des achats importants $\ldots$

- beaucoup plus

- un peu plus

- autant

- un peu moins

- beaucoup moins

- ne sait pas 


\section{Sweden}

Question 1 Hur ar ditt hushalls ekonomiska situation for narvarande jamfort med for 12 manader sedan? Ar den ...

- Mycket battre

- Nagot battre

- Ungefar lika

- Nagot samre

- Mycket samre

- Vet inte

Question 2 Hur tror du att ditt hushalls ekonomiska situation ar om 12 manader? Ar den ...

- Mycket battre

- Nagot battre

- Ungefar lika

- Nagot samre

- Mycket samre

- Vet inte

Question 3 Hur tycker du att den ekonomiska situationen ar $i$ Sverige for narvarande jamfort med for 12 manader sedan? Ar den ...

- Mycket battre

- Nagot battre

- Ungefar lika

- Nagot samre

- Mycket samre

- Vet inte

Question 4 Hur tror du att den ekonomiska situationen ar $i$ Sverige om 12 manader? Ar den...

- Mycket battre

- Nagot battre

- Ungefar lika

- Nagot samre

- Mycket samre

- Vet inte

Question 5 Jamfort med for 12 manader sedan, tycker du att priserna $i$ allmanhet for narvarande ar...

- Mycket hogre

- Ganska mycket hogre

- Nagot hogre

- Ungefar desamma

- Lagre 
- Vet inte

Question 6 Om du jamfor med dagens situation, tror du att priserna $i$ allmanhet om 12 manader kommer att ...

- Stiga snabbare

- Stiga i samma takt

- Stiga langsammare

- Vara i stort sett oforandrade

- Sjunka nagot

- Vet inte

Question 7 Hur tror du att arbetslosheten kommer att utvecklas under de narmaste 12 manaderna? Kommer den att ...

- Oka mycket

- Oka nagot

- Vara ungefar som nu

- Minska nagot

- Minska mycket

- Vet inte

Question 8 Har risken for att Du sjalv ska bli arbetslos under de senaste 12 manaderna ...?

- Oka mycket

- Oka nagot

- Vara ungefar som nu

- Minska nagot

- Minska mycket

- Vet inte

Question 9 Tycker du att det $i$ dagslaget ar fordelaktigt for folk $i$ allmanhet att gora stora inkop, som exempelvis mabler, tvattmaskiner, TV osv.?

- Ja, det ar ratt tidpunkt

- Varken ratt eller fel tidpunkt

- Nej, det ar fel tidpunkt, inkapet bar ske senare

- Vet inte

Question 10 Hur mycket pengar tror du att ditt hushall kommer att anvanda till inkop av sadana kapitalvaror under de narmaste 12 manaderna jamfort med de senaste 12 manaderna? Blir det ...

- Mycket mer

- Nagot mer

- Ungefar lika mycket

- Nagot mindre

- Mycket mindre

- Vet inte 
Question 11 Mot bakgrund av det allmanna ekonomiska laget, hur tycker du att det ar att spara for narvarande? Som sparande raknas aven minskning av eventuella lan. Ar det...

- Mycket fordelaktigt

- Ganska fordelaktigt

- Varken fordelaktigt eller ofordelaktigt

- Ganska ofordelaktigt

- Mycket ofordelaktigt

- Vet inte

Question 12 Hur troligt ar det att Ditt hushall kommer att kunna spara nagot under de narmaste 12 manaderna? Som sparande raknas aven minskning av eventuella lan. Ar det ...?

- Mycket troligt

- Ganska troligt

- Inte sarskilt troligt

- Inte alls troligt

- Vet inte

Question 13 Vilket av faljande pastaenden beskriver bast ditt hushalls nuvarande ekonomiska situation?

- Vi skuldsatter oss och/ eller utnyttjar sparade medel i stor utstrackning

- Vi skuldsatter oss och/ eller utnyttjar sparade medel

- Vi gar ungefar jamnt upp

- Vi sparar nagot

- Vi sparar mycket

- Vet inte 


\section{United Kingdom}

Question 1 How has the financial situation of your household changed over the last 12 months?

It has ...

- Got a lot better

- Got a little better

- Stayed the same

- Got a little worse

- Got a lot worse

- Don't Know

Question 2 How do you expect the financial position of your household to change over the next 12 months?

It will ...

- Get a lot better

- Get a little better

- Stay the same

- Get a little worse

- Get a lot worse

- Don’t Know

Question 3 How do you think the general economic situation in this country has changed over the past 12 months?

It has ...

- Got a lot better

- Got a little better

- Stayed the same

- Got a little worse

- Got a lot worse

- Don’t Know

Question 4 How do you expect the general economic situation in this country to develop over the next 12 months?

It will ...

- Get a lot better

- Get a little better

- Stay the same

- Get a little worse

- Get a lot worse

- Don't Know 
Question 5 How do you think consumer prices have developed over the last 12 months?

They have ...

- Risen a lot

- Risen moderately

- Risen slightly

- Stayed about the same

- Fallen

- Don’t Know

Question 6 In comparison with the past 12 months, how do you expect consumer prices will develop in the next 12 months?

They will ...

- Increase more rapidly

- Increase at the same rate

- Increase at a slower rate

- Stay about the same

- Fall

- Don't Know

Question 7 How do you expect the number of people unemployed in this country will change over the next 12 months?

The number will ...

- Increase sharply

- Increase slightly

- Remain the same

- Fall slightly

- Fall sharply

- Don't Know

Question 8 In view of the general economic situation, do you think now is the right time for people to make major purchases such as furniture or electrical goods?

- Yes, now is the right time

- It is neither the right time nor the wrong time

- No, it is the wrong time

- Don't Know

Question 9 Compared to the last 12 months, do you expect to spend more or less money on major purchases such as furniture and electrical goods?

I will spend ... 
- Much more

- A little more

- About the same

- A little less

- Much less

- Don't Know

Question 10 In view of the general economic situation, do you think that now is?

- A very good time to save

- A fairly good time to save

- Not a good time to save

- A very bad time to save

- Don’t Know

Question 11 Over the next 12 months, how likely will you be to save any money?

- Very likely

- Fairly likely

- Not likely

- Not at all likely

- Don't Know

Question 12 Which of these statements best describes the current financial situation of your household?

- We are saving a lot

- We are saving a little

- We are just managing to make ends meet on our income

- We are having to draw on our savings

- We are running into debt

- Don’t Know

\section{Data}

When conducting the survey, GfK also collects a rich set of demographics. We enlist the variables below, and report the possible values the variables obtained in the sample in parentheses.

Sex (male, female), age (continuous), household size $(1,2,3,4,5$ and more $)$, city size $(0 \leqslant$ size $\leqslant 1,999,2,000 \leqslant$ size $\leqslant 2,999,3,000 \leqslant$ size $\leqslant 4,999,5,000 \leqslant$ size $\leqslant 9,999$, $10,000 \leqslant$ size $\leqslant 19,999, \quad 20,000 \leqslant$ size $\leqslant 49,999, \quad 50,000 \leqslant$ size $\leqslant 99,999, \quad 100,000 \leqslant$ size $\leqslant 199,999$, $200,000 \leqslant$ size $\leqslant 499,999,500,000 \leqslant$ size), marital status (single, couple, married, widowed, divorced, separated), children at home (yes, no), number of children (1, 2, 3, 
4 and more), homeownership (house owner, apartment owner, renter), household head (yes, no), education (Hauptschule, Realschule, Gymnasium, University), employment (full-time, part-time, not employed), state (Schleswig-Holstein, Hamburg, Bremen, Berlin(West), Niedersachen, Nordrhein-Westfalen, Hessen, Rheinland-Pfalz, Saarland, Baden-Wuerttemberg, Bayern, Mecklenburg-Vorpommern, Sachsen-Anhalt, Brandenburg, Thueringen, Sachsen, Berlin(Ost)), monthly net income (inc) (inc $\leqslant 500$, $500<$ inc $\leqslant 750,750<$ inc $\leqslant 1,000,1,000<$ inc $\leqslant 1,2500,1,2500<$ inc $\leqslant 1,500,1,500<$ inc $\leqslant 2,000$, $2,000<$ inc $\leqslant 2,500,2,500<$ inc $\leqslant 3,000,3,000<$ inc $\leqslant 3,500,3,500<$ inc $\leqslant 4,000,4,000<$ inc $)$, job (farmer, liberal profession, self-employed, civil servant, white-collar worker, blue-collar worker, student, trainee, draftee, housewife, retiree, unemployed).

Data on the consumer price index, the unemployment rate, real durable consumption expenditure, real GDP, and industrial production are from the German Statistical Office (DeStatis); data on the European and German uncertainty index are from Baker et al. (2014); data on DAX and Volatility DAX are from the Deutsche Boerse; and oil price data are from Bloomberg.

We obtain the harmonized consumer price indexes (CPI) from the Statistical Data Warehouse at the European Central Bank. The data ID for the harmonized overall CPI is ICP.M.DE.N.000000.4.INX; for the all items CPI excluding food and energy it is ICP.M.DE.N.XEF000.4.INX; for the major durables CPI it is ICP.M.DE.N.0921_2.4.INX; and for the non-durable households goods CPI it is ICP.M.DE.N.056100.4.INX.

We obtain data for bank interest rates for loans to households in Germany for consumption from the Statistical Data Warehouse at the European Central Bank. The data ID is MIR.M.DE.B.A2B.A.R.A.2250.EUR.N. The rate is the annualized agreed rate, narrowly defined effective rate, for new loans for consumption excluding revolving loans and overdrafts, convenience and extended credit card debt.

Inflation expectations data for European Union member countries are from the European Commission Directorate on Economic and Financial Affairs.

Consensus forecasts of the one-year ahead the German consumer price inflation rate in percent at an annual rate are from Consensus Economics. The company surveys over 250 financial and economic professional forecasters for different macroeconomic variables such as future growth, inflation, interest rates, and exchange rates.

The ZEW Financial Market Experts Inflation Forecast Index is from the Center of 
European Economic Research (ZEW). ZEW Financial Market Survey is a monthly survey among 350 financial analysts and institutional investors in Germany. The survey asks participants about their six-month expectations concerning the economy, inflation rates, interest rates, stock markets, and exchange rates in Germany and other countries. The index is the difference between the fraction of surveyed financial experts which expect inflation to increase over the next six months minus the fraction of surveyed financial experts which expect inflation to decrease in percent.

The ECB Survey of Professional Forecasters (SPF) is a quarterly survey of expectations for the rates of inflation, real GDP growth, and unemployment in the euro area for several horizons. The participants to the Survey of Professional Forecasters are experts affiliated with financial or non-financial institutions based within the European Union.

\section{Press Clippings}

We briefly cite a few media quotes following the announcement of the newly-elected administration in 2005 to increase VAT by $3 \%$.

"Mehrwertsteuer ist glatter Betrug an den Waehler." Gruenen-Vorsitzende Claudia Roth haelt den Koalitionsvertrag fuer unsozial

"VAT is electoral fraud." Green party leader Claudia Roth calls coalition agreement antisocial

Berliner Morgenpost, 11/21/2005

Opposition kritisiert "Wahlbetrug." Vor allem hoehere Mehrwertsteuer stoesst auf Protest Opposition criticizes "electoral fraud." Especially higher VAT fiercely criticized

Frankfurter Rundschau, 11/14/2005

Opposition spricht von Wahlbetrug.

Opposition stresses "electoral fraud."

Die Welt, 11/13/2005

Die dreissten Steuerluegen.

Unapologetic tax lies. 
Westerwelle geisselt Steuererhoehungen.

Westerwelle criticizes tax hike.

Sueddeutsche Zeitung, 5/15/2006

Warum luegen Politiker?

Why do politician lie?

Welt am Sonntag, 5/14/2006

\section{Additional Results}

This section reports additional tests and robustness checks.

Figure A.1 plots inflation expectations for the European Union (EU), Germany, and several other EU membership countries. We observe an increase in inflation expectations immediately after the announcement of the VAT increase in Germany in November 2005 with high inflation expectations throughout 2006. Neither the European Union as a whole nor any of the individual member countries, including direct neighbor countries such as France or Austria, exhibit an increase in inflation expectations throughout 2006.

Figure A.2 plots the average treatment effect of the VAT increase on the readiness to buy durables, like Figure 9, but it also matches German and foreign households based on income expectations for the following twelve months in addition to gender, age group, education group, income group, and social status. The results are virtually identical.

Germany had negative residential property price inflation throughout our sample period and real GDP growth increased from 1.6\% in the last quarter of 2005 to $4.38 \%$ in the last quarter of 2006.

Figure 3 documents that the standardized one-year lagged inflation expectations index and the realized durable inflation rate track each other closely, and have a time series correlation of $65.37 \%$.

Months and years dummies to control for seasonality and aggregate effects and shocks have little impact on our findings (see columns (1) and (2) of Table A.1). We might also interpret the answers to the survey questions as ordered options and estimate an ordered probit model. Even in this case, we estimate marginal effects in line with our baseline 
estimates (see column (3)). A linear probability model estimates consistent marginal effects (column (4)). In column (5), we add a set of dummies for all the elicited answers on inflation expectations instead of our single dummy for an expected inflation increase. The average marginal effect of "prices will increase more" rises to $10.5 \%$. Households that expect prices to rise more in the next twelve months compared to the previous twelve months are also on average $3 \%$ less likely to say that it is a bad time to purchase durables.

Households that expect inflation to increase are also more likely to answer that it is a bad time to save (see Table A.2). 
Figure A.1: Expected Increase in Inflation
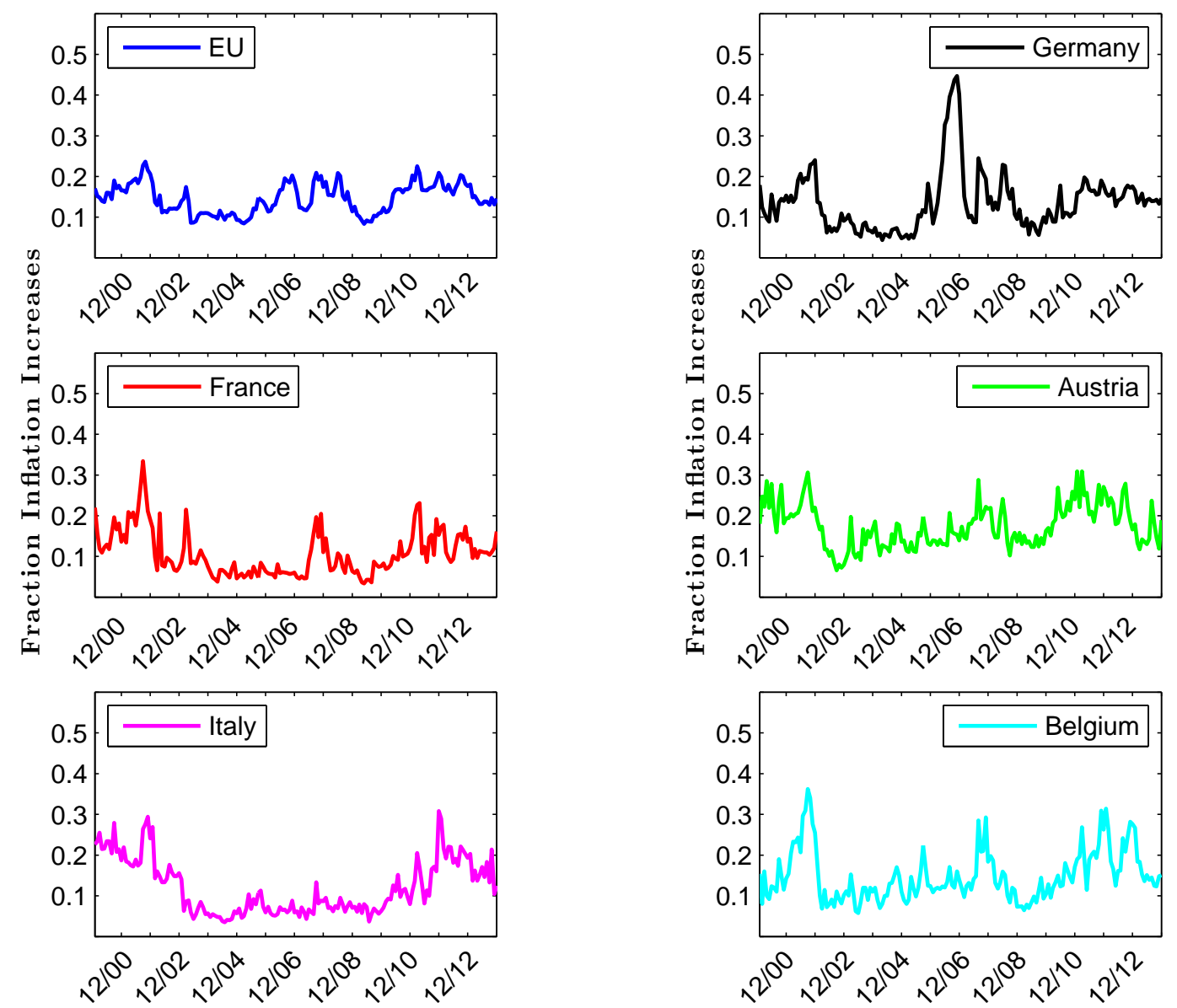

This figure plots average monthly inflation expectations over time. We use the time series data on consumer sentiment from the European Commission Directorate on Economic and Financial Affairs to construct these variables. We plot the fraction of households which expects inflation to increase. The sample period is January 2000 to December 2013 for a total of fourteen years. 
Figure A.2: Change in the Readiness to Spend on Durables for German vs. foreign households

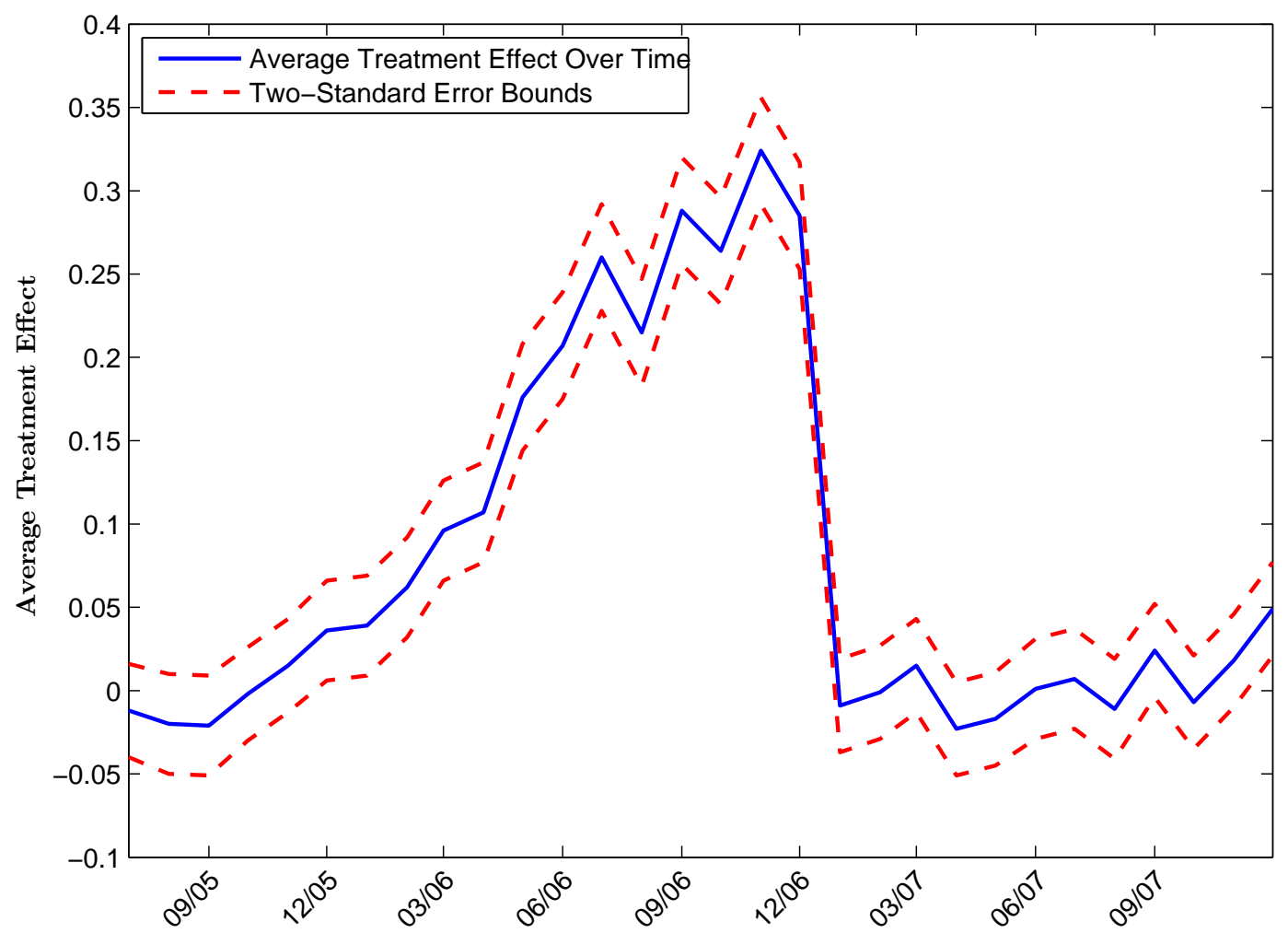

This figure plots the $\beta_{m}$ coefficient (solid line) of $\Delta D$ ur $r_{i, 06 / 2005 \rightarrow m}=\alpha+\beta_{m} \times V A T$ shock $k_{i}+\Delta X_{i, 06 / 2005 \rightarrow m}^{\prime} \times$ $\gamma+\epsilon_{i}$ and two standard deviation error bands (dashed line). $\Delta D u_{i, 06 / 2005 \rightarrow m}$ is the difference in the willingness to spend on durable goods between month $m$ and June 2005, VATshock $k_{i}$ is an indicator which equals 1 if the household was exposed to the VAT shock, $\beta_{m}$ captures the effect of the VAT shock on the willingness to buy durables for household $i$ in month $m$, and $\Delta X_{i, 06 / 2005 \rightarrow m}^{\prime}$ is the difference in a set of observables between month $m$ and the baseline month. We use the micro data underlying the DirectorateGeneral for Economic and Financial Affairs of the European Commission harmonized consumer surveys to construct these variables. 


\section{Table A.1: Inflation Expectations and Readiness to Spend: month \& year dummies, ordered probit, OLS, inflation dummies}

This table reports the average marginal effects of multinomial logit, ordered probit, and OLS regressions for different time periods. Households' readiness to purchase durables is the dependent variable. Inflation expectation is a dummy variable which equals 1 when a household replies that inflation will increase. Past inflation measures the household perception of the increase in consumer prices during the last twelve months. We also control for household demographics and household expectations. We use the confidential micro data underlying the GfK Consumer Climate MAXX survey to construct these variables. GfK asks a representative sample of 2,000 households on a monthly basis whether it is a good time to purchase durables given the current economic conditions. Households can reply that it is a good time, it is a bad time, or it is neither a good time nor a bad time. Standard errors are clustered at the quarter level. The sample period is January 2000 to December 2013 for a total of fourteen years. Column (1) adds month fixed effects; column (2) adds year fixed effects; column (3) estimates an ordered probit specification; column (4) estimates an OLS specification; column (5) adds separate dummies for inflation categories.

\begin{tabular}{lccccc}
\hline & $\begin{array}{c}\text { Month } \\
\text { dummies } \\
(1)\end{array}$ & $\begin{array}{c}\text { Year } \\
\text { dummies } \\
(2)\end{array}$ & $\begin{array}{c}\text { Ordered } \\
\text { probit } \\
(3)\end{array}$ & $\begin{array}{c}\text { OLS } \\
(4)\end{array}$ & $\begin{array}{c}\text { Inflation } \\
\text { dummies } \\
(5)\end{array}$ \\
\hline Inflation expectation & $0.0878^{* * *}$ & $0.0719^{* * *}$ & $0.0479^{* * *}$ & $0.0988^{* * *}$ & \\
& $(0.0151)$ & $(0.0070)$ & $(0.0139)$ & $(0.0272)$ & \\
Prices will increase less & & & & & $0.0234^{* * *}$ \\
& & & & & $(0.0061)$ \\
Prices will increase the same & & & & & $0.0202^{* * *}$ \\
& & & & & $0.0073)$ \\
Prices will increase more & & & & & $0.1048^{* * *}$ \\
& & & & & \\
Past Inflation & $-0.0200^{* * *}$ & $-0.0096^{* * *}$ & $-0.0291^{* * *}$ & $-0.0598^{* * *}$ & $-0.0237^{* * *}$ \\
& $(0.0035)$ & $(0.0026)$ & $(0.0029)$ & $(0.0061)$ & $(0.0034)$ \\
\hline Demographics & & & & & $\mathrm{X}$ \\
Individual expectations & $\mathrm{X}$ & $\mathrm{X}$ & $\mathrm{X}$ & $\mathrm{X}$ & $\mathrm{X}$ \\
Pseudo_R-sqr & 0.0657 & 0.0819 & 0.0564 & 0.1056 & 0.0657 \\
Nobs & 219,799 & 219,799 & 219,799 & 219,799 & 215,579 \\
\hline
\end{tabular}

Standard errors in parentheses

$* p<0.10, * * p<0.05, * * * p<0.01$ 


\section{Table A.2: Inflation Expectations and Readiness to Save}

This table reports the average marginal effects of a multinomial logit regression. Households' readiness to save is the dependent variable. Inflation expectation is a dummy variable which equals 1 when a households replies that inflation will increase. Past inflation measures the household perception of the increase in consumer prices during the last twelve months. We use the confidential micro data underlying the GfK Consumer Climate MAXX survey to construct these variables. GfK asks a representative sample of 2,000 households on a monthly basis whether it is a good time to purchase durables given the current economic conditions. Households can reply that it is a good time, it is probably a good time, it is not really a good time, or it is not at all a good time. Standard errors are clustered at the quarter level. The sample period is January 2000 to December 2013 for a total of fourteen years.

\begin{tabular}{lccc}
\hline & $\begin{array}{c}\text { Not at all } \\
(1)\end{array}$ & $\begin{array}{c}\text { Not really } \\
(2)\end{array}$ & $\begin{array}{c}\text { Good time } \\
(3)\end{array}$ \\
\hline Inflation increase & $0.0160 * * *$ & $0.0082 * *$ & 0.0006 \\
& $(0.0016)$ & $(0.0036)$ & $(0.0082)$ \\
Past Inflation & $0.0019 * *$ & $-0.0134 * * *$ & $0.0332 * * *$ \\
& $(0.0007)$ & $(0.0023)$ & $(0.0045)$ \\
& & & \\
\hline Demographics & $\mathrm{X}$ & $\mathrm{X}$ & $\mathrm{X}$ \\
Individual expectations & $\mathrm{X}$ & $\mathrm{X}$ & $\mathrm{X}$ \\
Pseudo $\mathrm{R}^{2}$ & & 0.0203 & \\
Nobs & & 234,522 & \\
\hline Standard & & &
\end{tabular}

Standard errors in parentheses

$* p<0.10, * * p<0.05, * * * p<0.01$ 


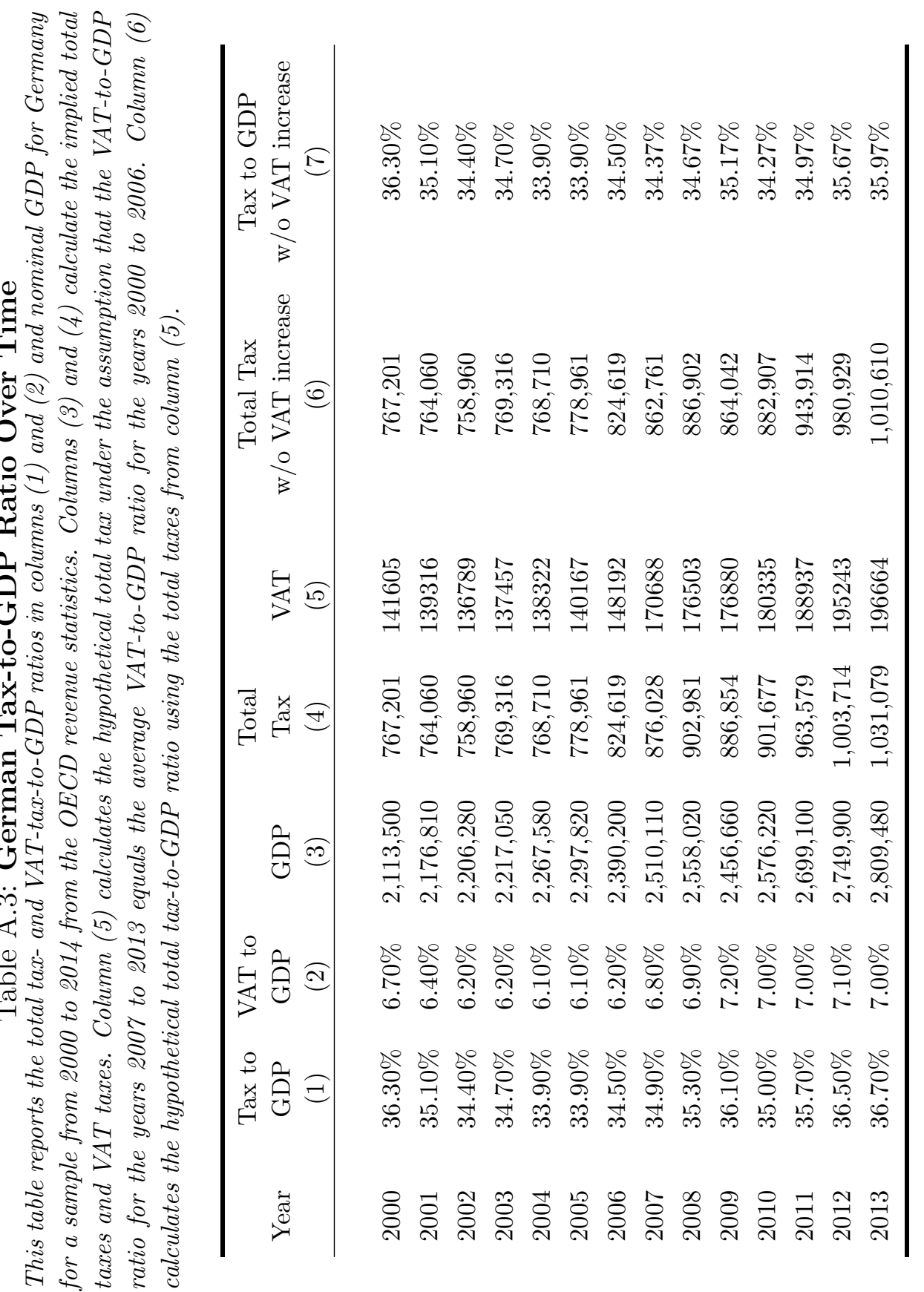

